\title{
Catalytic Strategies Towards Lignin-Derived Chemicals
}

\author{
S. Van den Bosch ${ }^{1}$ (D) S.-F. Koelewijn ${ }^{1}$ (D) . T. Renders ${ }^{1}$ (D) . G. Van den Bossche ${ }^{1}$. \\ T. Vangeel ${ }^{1} \cdot$ W. Schutyser ${ }^{1} \cdot$ B. F. Sels ${ }^{1}$ (D)
}

Received: 29 June 2018 / Accepted: 10 August 2018

(c) Springer Nature Switzerland AG 2018

\begin{abstract}
Lignin valorization represents a crucial, yet underexploited component in current lignocellulosic biorefineries. An alluring opportunity is the selective depolymerization of lignin towards chemicals. Although challenged by lignin's recalcitrant nature, several successful (catalytic) strategies have emerged. This review provides an overview of different approaches to cope with detrimental lignin structural alterations at an early stage of the biorefinery process, thus enabling effective routes towards lignin-derived chemicals. A first general strategy is to isolate lignin with a better preserved native-like structure and therefore an increased amenability towards depolymerization in a subsequent step. Both mild process conditions as well as active stabilization methods will be discussed. An alternative is the simultaneous depolymerization-stabilization of native lignin towards stable lignin monomers. This approach requires a fast and efficient stabilization of reactive lignin intermediates in order to minimize lignin repolymerization and maximize the envisioned production of chemicals. Finally, the obtained lignin-derived compounds can serve as a platform towards a broad range of bio-based products. Their implementation will improve the sustainability of the chemical industry, but equally important will generate opportunities towards product innovations based on unique biobased chemical structures.
\end{abstract}

Keywords Biorefinery $\cdot$ Lignin $\cdot$ Lignocellulose $\cdot$ Catalysis $\cdot$ Biobased chemicals

This article is part of the Topical Collection "Lignin Chemistry"; edited by Luis Serrano, Rafael Luque, Bert Sels.

S. Van den Bosch

sander.vandenbosch@kuleuven.be

$\square$ B. F. Sels

bert.sels@kuleuven.be

1 Center for Surface Chemistry and Catalysis, KU Leuven, Celestijnenlaan 200F, 3001 Heverlee, Belgium 


\section{Introduction}

Today, alternative technologies are being developed to reduce our society's dependency on fossil resources [1-4]. Several renewable resources, viz., hydro, solar, wind, hydrothermal, and biomass, can be applied for the production of electricity or heat, but only biomass possesses a carbon precursor structure that is required to synthesize chemicals, materials, and liquid transportable fuels. In this light, the concept of the biorefinery, in which biomass is converted to marketable products, is receiving a lot of attention [4-6]. Lignocellulose, the most abundant type of biomass on earth, is regarded as a highly promising feedstock, though its sustainable exploitation should be closely managed; this is likely more realistic in the context of medium volume applications such as chemicals and materials [7,8].

Due to lignocellulose's complex matrix of entangled biopolymers, viz., cellulose, hemicellulose, and lignin, biorefineries often apply a fractionation strategy to lower the complexity and to allow a tailored downstream conversion of each of these fractions to targeted products [4-6]. Whereas traditional biorefineries primarily focus on the carbohydrate fraction, e.g., for paper and pulp or bio-ethanol production, lignin valorization is becoming increasingly recognized as a crucial link in the valorization chain [9-11]. A major obstacle, however, is lignin's strong tendency towards irreversible degradation, resulting in a recalcitrant lignin-derived side-stream that is usually incinerated for energy recuperation or electricity production [12-14]. Since lignin constitutes the largest source of aromatic compounds in nature, its full valorization potential is nonetheless far from reached. An alternative to incineration is the use of lignin for macromolecular applications such as binding and dispersing agents, polymer composites, and carbon nanofibers, which forms the subject of a highly active research field [11,15-19]. More recently, the utilization of lignin as a feedstock for chemicals came into the spotlight, and this forms the topic of this chapter (see Fig. 1).

After a brief introduction on the compositional and structural features of lignocellulosic biomass (Sect. 2), traditional lignocellulose fractionation methods will be discussed with emphasis on the ongoing lignin chemistry (Sect. 3). Subsequently,

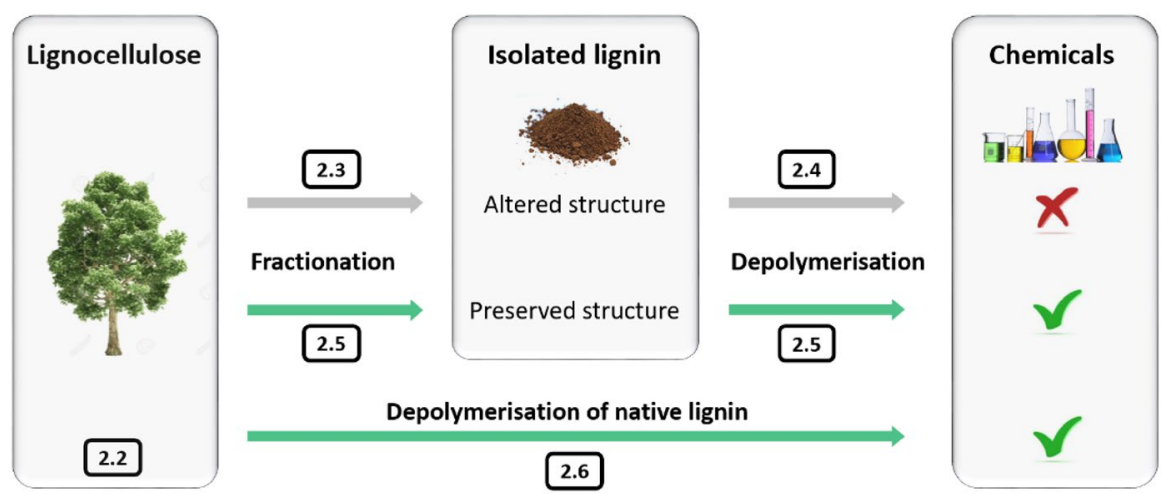

Fig. 1 Schematic overview of major lignin valorization strategies to chemicals discussed in this chapter 
major lignin depolymerization strategies will be reviewed, illustrating the recalcitrant nature of lignin upon traditional isolation (Sect. 4). The reactivity of native lignin can be (partially) preserved during milder fractionation processes, hereby enabling a more selective and high-yield production of chemicals from isolated lignin (Sect. 5). Alternatively, the selective depolymerization of lignin into stable products can be performed already during the fractionation step. This strategy will be discussed in Sect. 6. Finally, a perspective on lignin-derived chemicals is provided in Sect. 7.

\section{Lignocellulosic Biomass}

Lignocellulose, the main constituent in plant cell walls, represents the most abundant source of biomass on earth [20,21]. Its widespread availability and limited interference with the food industry have turned this biomass feedstock into a favorable renewable candidate for the future chemical industry [22]. The most important sources of lignocellulosic biomass are forestry (hardwoods and softwoods) and agricultural wastes (e.g., corncob, corn stover, rice straw, and wheat straw) next to fast-growing perennial grasses like Miscanthus and switchgrass [23]. An impeding factor, however, is lignocellulose's recalcitrance towards chemical and biological conversion, originating from its natural role as a structural and antimicrobial component in plants $[24,25]$. This recalcitrant behavior is mainly caused by strong covalent and non-covalent interactions between the three major biopolymers, i.e., cellulose, hemicellulose, and lignin, which together form the lignocellulose matrix, as illustrated in Fig. 2. Briefly, cellulose is organized into highly ordered fibrillary macrostructures, which are supported by a complex intertwined network of hemicellulose and lignin polymers $[21,26]$. The fraction represented by each of these three constituents, as well as their chemical composition, varies significantly within different biomass substrates [27-29]. In addition, other compounds such as pectin, proteins, ashes, terpenes, waxes, and fatty acids are also present, albeit in smaller amounts. Altogether, this contributes to the heterogeneous nature of the lignocellulosic feedstock.

Cellulose is the main biopolymer in plant cell walls, constituting roughly $35-55 \%$ of the lignocellulosic biomass. It is defined as a linear homo-polysaccharide, composed out of D-glucopyranose units (up to 104), which are linked via $\beta-1,4$ glycosidic bonds $[30,31]$. The obtained polymer has a strong tendency towards intra- and inter-unit hydrogen bonding, which in combination with van der Waals forces and hydrophobic forces results in the formation of organized crystalline zones [30, 31]. In cellulose, crystalline domains co-exist with less-ordered amorphous zones, leading to a semi-crystalline macrostructure, which is insoluble in water and has a very high tensile strength. These properties are critical to provide both chemical stability and mechanical strength to the plant, but at the same time hamper downstream conversion towards fuels (e.g., bio-ethanol) or chemicals (e.g., levulinic acid, sorbitol) [30].

In contrast to cellulose, hemicellulose is a branched hetero-polysaccharide with a variety of monomer building blocks. Typically, hemicellulose comprises a linear 


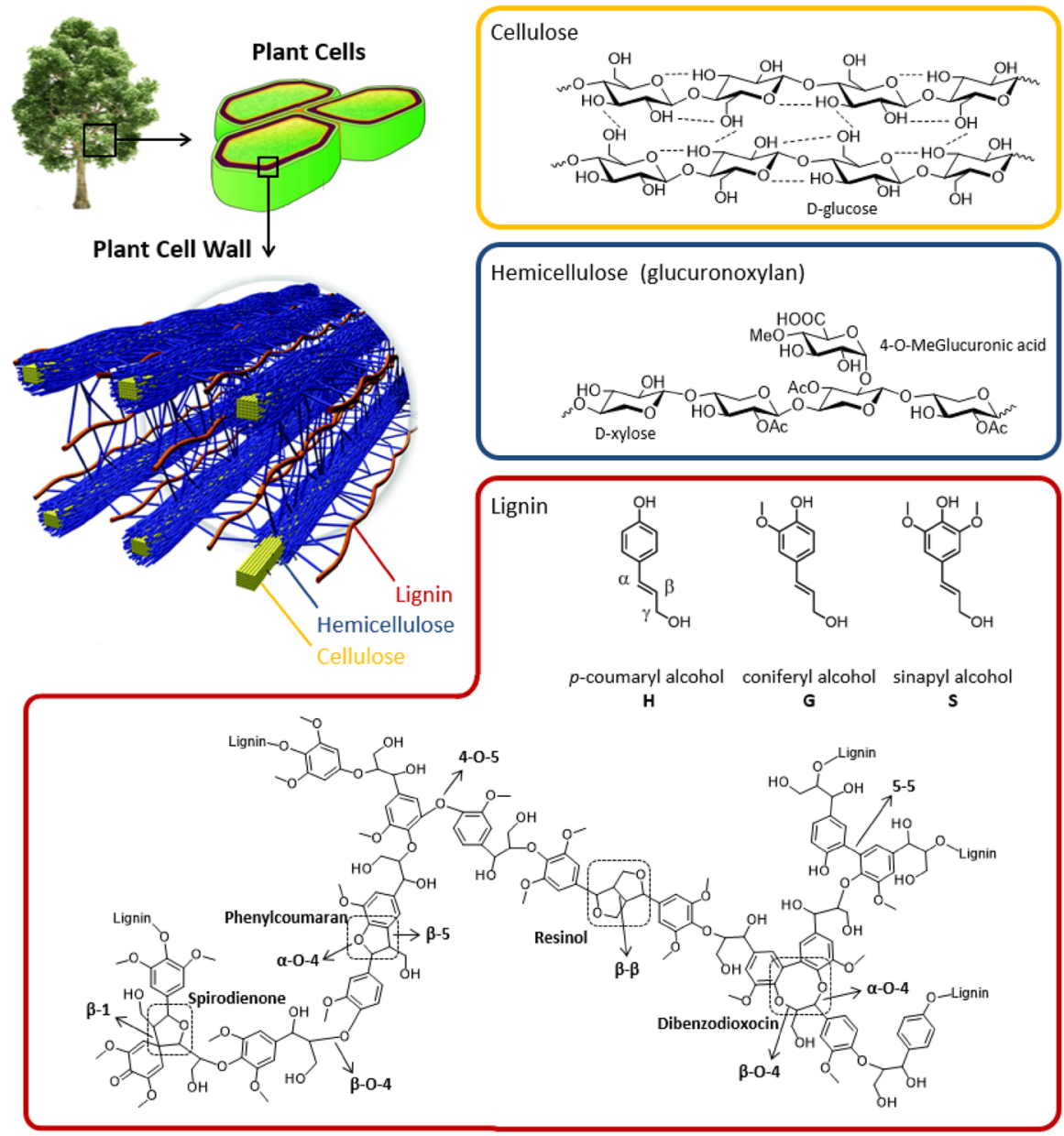

Fig. 2 Schematic illustration of the lignocellulose matrix [35] in plant cell walls, mainly composed of three biopolymers: cellulose, hemicellulose and lignin Adapted from Sels et al. [36]

polymer chain of D-xylose (e.g., glucuronoxylan in hardwoods, illustrated in Fig. 2, or arabinoglucuronoxylan in grasses or softwoods) or D-glucose and D-mannose (e.g., galactoglucomannan in softwoods) linked through $\beta-1,4$ glycosidic bonds [32, 33]. The addition of L-arabinose, D-galactose, uronic acids, and acetyl groups on the linear chain generates a branched amorphous structure that is relatively prone to biological or chemical attack. Hemicellulose makes up 10-35\% of lignocellulosic biomass and has a lower degree of polymerization compared to cellulose, typically ranging from 50 to 300 units $[33,34]$. Hemicellulose's main biological function is to reinforce the cell wall by tethering cellulose microfibrils and participating in the construction of covalently bonded lignin-carbohydrate complexes (LCCs) [21].

Lignin is the third major component, representing about $15-30 \%$ of the lignocellulose matrix [14, 37]. This polymer has an amorphous aromatic structure and plays 
a vital role in plant's antimicrobial defense mechanism [26]. By strongly interacting with hemicellulose, through LCCs, lignin also supports cellulose fibres, thus contributing to the rigidity of the plant cell wall $[38,39]$.

The lignin polymer is primarily synthesized from three monolignols, i.e., $p$-coumaryl $(\mathrm{H})$, coniferyl $(\mathrm{G})$, and sinapyl alcohol $(\mathrm{S})$, which possess 0 , 1 , or 2 orthomethoxy-groups, respectively. Once incorporated in the lignin polymer chain, the corresponding phenolic units are denominated as $p$-hydroxyphenyl $(\mathrm{H})$, guaiacyl $(\mathrm{G})$, and syringyl (S) units [13, 33]. Through enzyme-catalyzed H-abstraction of the phenolic $\mathrm{OH}$-group, resonance-stabilized radicals are formed. The delocalized electrons enable radical coupling reactions at several positions, leading to various types of inter-unit linkages (see Fig. 2), being either $\mathrm{C}-\mathrm{C}$ bonds or ether bonds [40, 41]. With a relative contribution of 50-80\%, the $\beta-\mathrm{O}-4$ ether bond is by far the most abundant inter-unit linkage in lignin [14]. Other common structures are phenylcoumaran $(\beta-5+\alpha-\mathrm{O}-4)$, resinol $(\beta-\beta+\alpha-\mathrm{O}-\gamma)$, spirodienone $(\beta-1+\alpha-\mathrm{O}-\alpha)$, biphenyl (5-5), dibenzodioxocin (5-5 $+\alpha-\mathrm{O}-4+\beta-\mathrm{O}-4)$, and diphenyl ether (4-O-5) [37, 41]. From these linkages, the $\alpha-\mathrm{O}-4$ and $\beta-\mathrm{O}-4$ bonds are most readily cleaved during processing. However, since $\alpha-\mathrm{O}-4$ bonds are mostly present in combination with more resilient $\mathrm{C}-\mathrm{C}$ linkages, cleavage of the $\alpha-\mathrm{O}-4$ bond has no direct effect on the extent of lignin depolymerization. Due to its high abundancy and readily cleavable nature, the $\beta-\mathrm{O}-4$ bond is the most investigated inter-unit linkage in lignin research.

The distribution of inter-unit linkages in lignin varies significantly with different sources of lignocellulose. An important variable is the ratio of the $\mathrm{H}, \mathrm{G}$, and $\mathrm{S}$ building blocks in the lignin polymer. Since methoxy groups occupy either one or both of the ortho-positions (relative to the phenolic group) on the aromatic ring, they block the formation of resilient $\beta-5$ and 5-5 bonds. For this reason, lignin with a higher content of methoxy groups $(\mathrm{S}>\mathrm{G}>\mathrm{H})$ contains a lower fraction of resistant $\mathrm{C}-\mathrm{C}$ bonds and therefore has a higher susceptibility towards extensive depolymerization [42-44]. Hardwood lignin has a high S-content (50-80\%) and a smaller fraction of $\mathrm{G}$ units, whereas softwood lignin is almost completely composed out of $\mathrm{G}$ units $[14,37]$. Consequently, hardwood lignin typically contains a higher amount of ether bonds compared to softwood lignin (60 vs. 45-50\%) [14, 42]. Finally, lignin in herbaceous crops is predominantly built from $\mathrm{G}$ units (55-70\%) next to smaller amounts of S and H compounds [45-47].

\section{Lignin Chemistry During Biomass Fractionation}

The objective of any biorefinery is the conversion of biomass into a spectrum of marketable products. Due to the heterogeneous and complex nature of the lignocellulose matrix, a fractionation strategy is often applied, prior to tailored processing of each individual product stream. As the pulp and paper industry played a dominant role in the landscape of lignocellulosic biorefining during the 19th and 20th centuries, many traditional fractionation processes are geared towards efficient isolation and purification of a fibrous cellulose product stream [48, 49]. With the more recent emergence of the second-generation bio-ethanol industry, again technological efforts are focused on the carbohydrate fraction [50, 51]. In both carbohydrate-oriented 
contexts, lignin is perceived as an uninteresting constituent due to its contribution to biomass recalcitrance, which impedes carbohydrate valorization $[52,53]$. Therefore, lignocellulose is processed under harsh conditions to separate the carbohydrates from lignin, causing irreversible chemical alterations in lignin's chemical structure. The resulting lignin side-stream has long been considered a waste product and is mostly burned for process heat and electricity [13, 37]. In this chapter, the most common (industrial) fractionation processes are summarized and the impact of each of those methods on the chemical structure of lignin is highlighted, especially with regard to the fate of $\beta-\mathrm{O}-4$ bonds.

\subsection{Base-Catalyzed Fractionation}

\subsubsection{Application and Mechanism}

Alkaline media are widely applied for the removal of lignin from lignocellulosic feedstock. Major sources of commercial lignin (e.g., sulphite, kraft, soda) are obtained through alkaline lignocellulose fractionation in the pulp and paper industry [54]. An important reason for this is the base-catalyzed deprotonation of phenolic and benzylic OH-groups in lignin (see Fig. 3), resulting in the formation of ionic intermediates with an improved water-solubility, compared to native lignin $[12,55,56]$. Lignin ionization therefore enhances the extraction of lignin from the lignocellulose matrix. Several other base-catalyzed reactions further impact lignin depolymerization and thus its extraction (Fig. 3). For instance, deprotonation of the benzylic $\mathrm{OH}$-group in non-phenolic units initiates

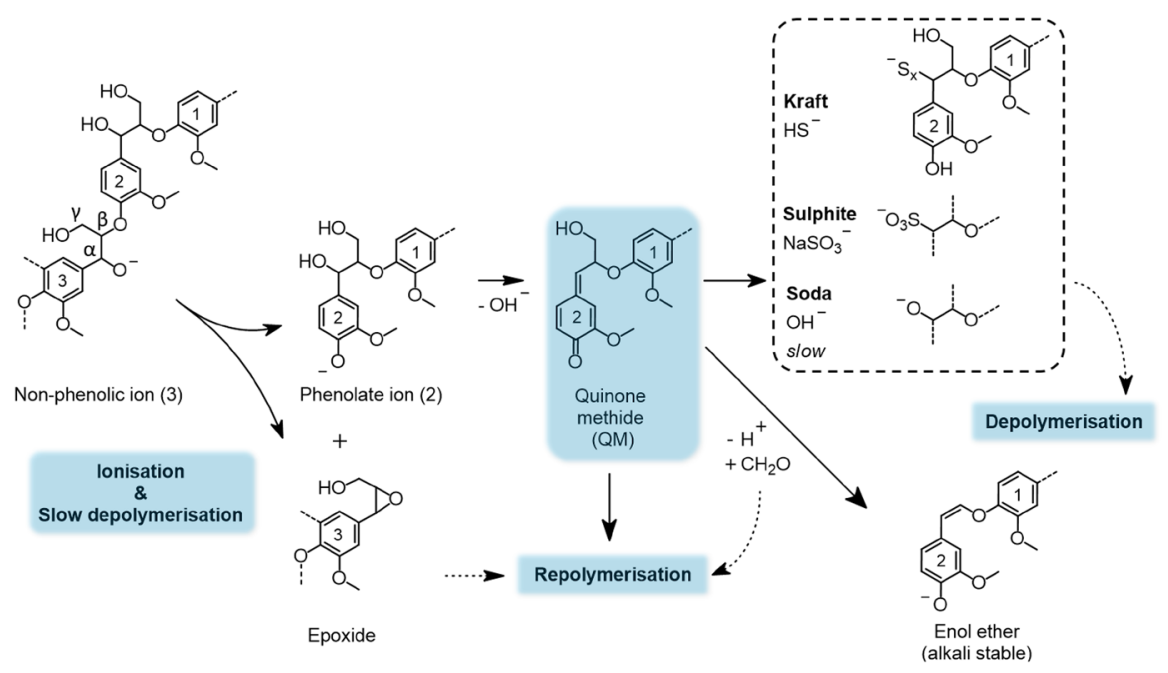

Fig. 3 Fate of the $\beta-O-4$ ether bond during base-catalyzed fractionation of lignocellulosic biomass: a balance between ionization (deprotonation), depolymerization (ether bond cleavage), and repolymerization (C-C bond formation) reactions 
slow $\beta-\mathrm{O}-4$ bond cleavage, resulting in additional phenolate ions, but also in the formation of epoxides, which readily participate in repolymerization reactions $[56,57]$. Phenolate ions are readily converted to quinone methide (QM) intermediates, provided that a good leaving group $(-\mathrm{OH},-\mathrm{OR})$ is present at the benzylic position $[55,56,58]$. The QM has a strong tendency to restore the aromaticity, which can occur through several reaction pathways. The selectivity to which these pathways occur has a large influence on the final lignin product properties, making the QM a key intermediate during alkaline biomass fractionation. Nucleophilic attack on the QM can induce further lignin depolymerization via ether bond cleavage, but can just as well introduce new $\mathrm{C}-\mathrm{C}$ bonds via repolymerization with lignin-derived nucleophiles $[55,56,58]$. A third route to restore QM's aromaticity is by breaking the $\mathrm{C}_{\beta}-\mathrm{C}_{\gamma}$ bond in the aliphatic side-chain, thus creating an alkali-stable enol-ether. The hereby released formaldehyde might, however, introduce additional $\mathrm{C}-\mathrm{C}$ linkages, through phenol-formaldehyde condensation reactions $[14,56,59]$. This intricate balance between solubilization, depolymerization and repolymerization determines the lignin product outcome and differs for several important base-catalyzed fractionation processes (e.g., kraft, sulphite, soda), as discussed next.

\subsubsection{Kraft Pulping}

The kraft process is today's dominant chemical pulping process, reaching a global market share of over $90 \%$ and an annual pulp production volume of around 130 MT [14, 60, 61]. During the kraft process, lignocellulose is fractionated in an aqueous solution of $\mathrm{NaOH}$ and $\mathrm{Na}_{2} \mathrm{~S}$ at temperatures around $443 \mathrm{~K}[59,61]$. This results in a solid cellulose-enriched pulp and a liquid product stream called 'black liquor', which contains a mixture of soluble lignin and hemicellulose components. Although the kraft process produces the largest lignin product stream in industry, at this moment, only a small portion $(<2 \%)$ is actually available as isolated kraft lignin $[13,54]$. The reason for this is the predominant incineration of black liquor for the generation of electricity and heat, as well as the regeneration of $\mathrm{Na}_{2} \mathrm{~S}$ [14]. Nevertheless, lignin can be readily isolated from the black liquor, for instance via precipitation induced by neutralization of the alkaline liquor [62]. It is important to emphasize that isolated kraft lignin has a strongly altered chemical structure compared to native lignin $[47,55]$. Strong nucleophilic $\mathrm{HS}^{-}$ions, present during the process, react with the $\alpha$-carbon of QMs, hereby initiating $\beta-\mathrm{O}-4$ cleavage and the incorporation of sulphur, ultimately ending up in the form of thiol groups. Furthermore, the alkaline conditions promote a complex network of repolymerization reactions [14], briefly discussed in the context of Fig. 3. As a result, kraft processing leads to a condensed, recalcitrant, and water-insoluble lignin product, which has lost most of the native $\beta-\mathrm{O}-4$ ether bonds and possesses a (relatively low) sulphur content of $1-3 \%$, which is known to act as a catalyst poison [14, 54, 63]. Kraft lignin therefore represents a challenging feedstock for catalytic conversions to chemicals and fuels. 


\subsubsection{Sulphite Pulping}

Sulphite pulping was the dominant process until the 1950s, but has since been superseded by the more flexible kraft process and now represents less than $10 \%$ of the chemical pulping industry $[55,64]$. By adjusting the cation $\left(\mathrm{Na}^{+}, \mathrm{NH}_{4}{ }^{+}, \mathrm{Mg}^{2+}\right.$, $\mathrm{Ca}^{2+}$ ) of the sulphite or bisulphite salt, the process can proceed under a wide range of $\mathrm{pHs}$, from 1 to $13[55,65]$. Although the underlying mechanism is $\mathrm{pH}$-dependent, typically the benzylic $\alpha$-carbon in lignin is sulphonated upon nucleophilic attack of the (bi)sulphite anion, which is followed by the cleavage of $\beta-\mathrm{O}-4$ bonds $[56,66]$. The resulting lignosulphonates have a higher sulphur content (4-8\%) compared to kraft lignin and possess a greatly improved solubility in water (even at low $\mathrm{pH}$ ), which has enabled their implementation as a macromolecular component in multiple applications (e.g., dispersants, adhesives) [65, 66]. Lignosulphonate's good solubility in water slightly complicates their isolation, though several techniques such as ultrafiltration, extraction, or precipitation are being successfully applied [66, 67]. Due to their high applicability and feasible isolation, lignosulphonates represent the largest commercial source of lignin at this moment, despite the smaller production capacity of the sulphite process [54].

\subsubsection{Soda Pulping}

The soda process is a third important fractionation method used in the pulping industry. It is similar to kraft processing, but uses an aqueous $\mathrm{NaOH}$ solution without $\mathrm{Na}_{2} \mathrm{~S}$ [65]. The absence of a strong nucleophile leads to a less-efficient cleavage of $\beta-\mathrm{O}-4$ bonds and steers the QM intermediate towards repolymerization pathways, discussed previously (see Fig. 3) [55, 65]. Therefore, soda pulping is primarily used for the fractionation of herbaceous feedstock (e.g., perennial grasses, agricultural residues), which typically possess a more accessible structure, a lower lignin content, and a higher amount of alkali-unstable ester linkages [62, 63]. To increase the fractionation efficiency during soda-pulping, anthraquinone is often used, because it can act as a redox shuttle to promote ether bond cleavages (reductive) and stabilize the carbohydrate fraction (oxidative) [61, 68]. A major advantage of the soda pulping process is the production of a more valuable sulphur-free lignin, thus avoiding catalyst poisoning or bad odors (often linked to sulphur) during downstream lignin processing $[63,69]$.

\subsection{Acid-Catalyzed Fractionation}

\subsubsection{Application and Mechanism}

Acidic media are traditionally applied in lignocellulose fractionation to catalyze the hydrolytic cleavage of glycosidic bonds in hemicellulose and cellulose [70, 71]. This results in the formation of soluble mono- and oligomeric carbohydrates, ready for downstream bio- or chemocatalytic processing. The process severity can also be 
reduced to perform a selective hydrolysis of hemicellulose while retaining the more stable cellulose as a solid product fraction [12, 70, 72]. In contrast to base-catalyzed fractionation, acidic conditions do not exert a direct promoting effect on the solubilization of lignin [72, 73]. However, a complex network of acid-catalyzed reactions evokes lignin depolymerization and repolymerization, hereby altering the chemical structure of the native lignin polymer [73, 74]. Depending on the process conditions and setup, the final lignin product is either obtained as a highly degraded solid residue or as a solubilized product that in certain cases can be separated from the solubilized carbohydrates through lignin precipitation. Before discussing traditional acid-catalyzed fractionation processes, a general introduction on the underlying acid-catalyzed lignin chemistry is provided.

Due to its high abundance and readily cleavable nature, the fate of the $\beta-\mathrm{O}-4$ ether bond has a major impact on the final lignin properties. In acidic media, $\beta-\mathrm{O}-4$ bond cleavage is initiated via protonation and subsequent dehydration of the benzylic OH-group, resulting in a benzylic carbocation (see Fig. 4) [74]. This ion can either undergo (1) proton abstraction or (2) $\mathrm{C}_{\beta}-\mathrm{C}_{\gamma}$ bond cleavage, which in both cases leads to the formation of an enol-ether. Acid-catalyzed hydration of the $\mathrm{C}_{\alpha}=\mathrm{C}_{\beta}$ double bond generates a hemiketal or hemiacetal, which after $\beta$-O-4 bond cleavage results in a carbonyl group on the $\beta$-carbon $[74,75]$. Ketone-substituted phenolics (route $\mathrm{I}$ ) have a $\mathrm{C}_{3}$-side-chain and are denominated as Hibbert ketones, whereas the aldehyde-substituted phenolics (route II) have a $\mathrm{C}_{2}$-side-chain resulting from the release of $\mathrm{CH}_{2} \mathrm{O}$ upon $\mathrm{C}_{\beta}-\mathrm{C}_{\gamma}$ bond cleavage [75-77]. Besides its conversion to enol-ethers, the carbenium ion is also prone to undergo nucleophilic attack, leading to repolymerization reactions with for

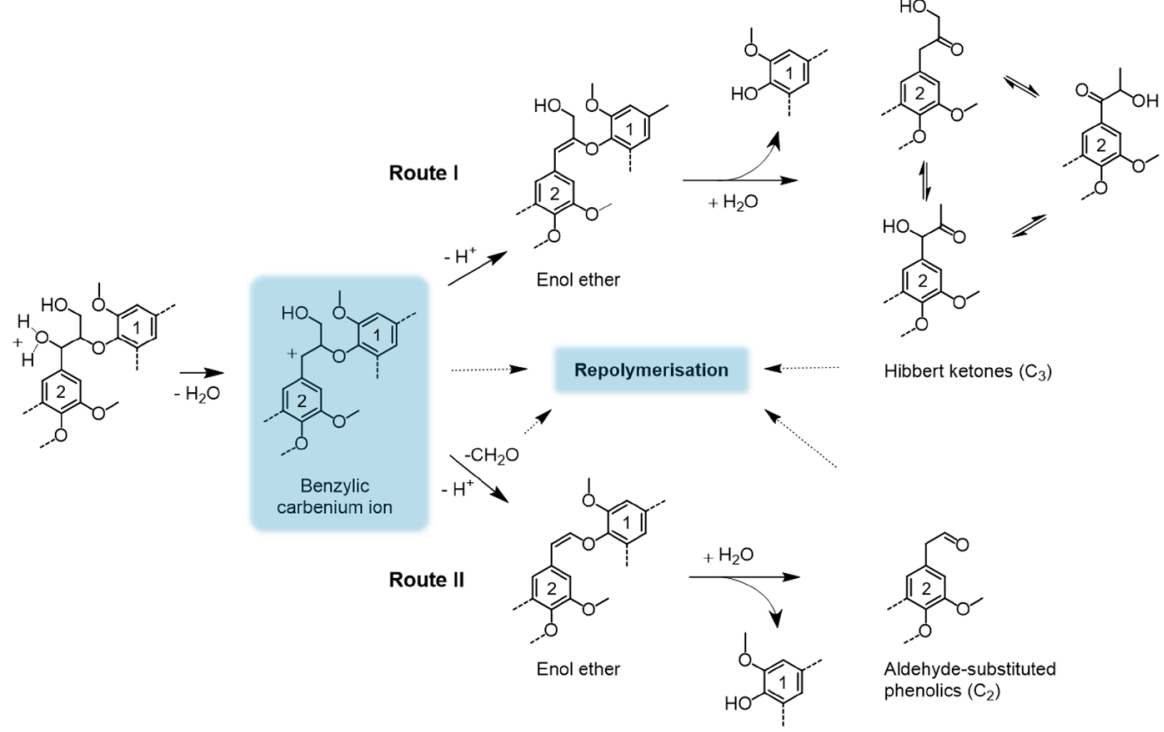

Fig. 4 Fate of the $\beta$-O-4 ether bond during acid-catalyzed fractionation of lignocellulosic biomass, illustrating a multitude of lignin intermediates, reactive towards repolymerization 
instance the electron-rich meta-positions on the aromatic ring [78, 79]. Note that the electron density on the aromatic ring is $\mathrm{pH}$-dependent, shifting from the ortho-position at high $\mathrm{pH}$ to the meta-position at low $\mathrm{pH}$ [78]. Moreover, a complex network of repolymerization reactions occurs between carbenium ions, formaldehyde, Hibbert ketones, and $\mathrm{C}_{2}$-aldehyde substituted phenolics [73, 76, 80]. This ultimately results in a condensed lignin structure, in which the extent of ether bond cleavage and $\mathrm{C}-\mathrm{C}$ bond formation is related to the severity and characteristics of the applied fractionation process.

\subsubsection{Concentrated Acid Hydrolysis (CAH)}

$\mathrm{CAH}$ is a traditional fractionation method in which cellulose and hemicellulose are efficiently hydrolyzed, reaching yields of over $90 \%$ towards water-soluble oligosaccharides [81, 82]. The use of concentrated aqueous acidic solutions (e.g., 42-66 wt\% $\mathrm{HCl}$ ) allows the physicochemical disruption and (partial) depolymerization of insoluble crystalline cellulose fibrils at ambient temperature. However, a post-hydrolysis step under diluted conditions ( $<5 \mathrm{wt} \%$ acid) and increased temperature is often applied to further depolymerize the soluble carbohydrates towards monomeric pentose and hexose sugars [70,81, 82]. Overall, the native lignin structure is exposed to strongly acidic conditions, causing nearly complete removal of $\beta-\mathrm{O}-4$ bonds and a high extent of repolymerization reactions, as discussed within the context of Fig. 4. As a result, lignin is primarily retained as an insoluble highly degraded residue, apart from a small fraction of acid-soluble lignin monomers and short oligomers [83]. The solid lignin residue is easily isolated from the solubilized carbohydrate fraction via filtration. Due to its high fractionation efficiency, this approach is also often used as an analytical tool to determine the amount of lignin (e.g., Klason lignin) and carbohydrates in lignocellulosic materials [83, 84].

\subsubsection{Dilute Acid Hydrolysis (DAH)}

However, the use of high acid concentrations has some economical drawbacks like severe metal corrosion and inefficient acid recovery [70, 85]. This instigated the development of dilute acid hydrolysis methods. Although preferred by industry, the much lower acidity of the process medium ( $<10 \mathrm{wt} \%$ acid) strongly increases the required temperature $(>373 \mathrm{~K})$ to hydrolyze the inaccessible crystalline cellulose domains. This in turn leads to unwanted thermal degradation reactions, like sugar dehydration to furans and repolymerization to humins [86, 87]. Moreover, acid-catalyzed reactions (Fig. 4) produce a degraded solid lignin residue, contaminated with insoluble carbohydrate degradation products, often called pseudo-lignin [87-89]. High rates of sugar degradation compared to (hemi) cellulose depolymerization can be tackled by shortening the residence time, which triggered the development of flow-through reactor setups [70]. This also has a positive impact on the preservation of the original lignin structure, as will be discussed in Sect. 5.1. 


\section{3 (Aqueous) Organosolv Fractionation}

Organic solvents have been introduced in biomass fractionation strategies as a way to increase the solubility of lignin in the processing liquor, hereby minimizing lignin redeposition on the cellulose pulp, as observed during mild acid lignocellulose pretreatment $[90,91]$ and ensuring a more efficient isolation of lignin in a broader range of process conditions [92-95]. Note the analogy with base-catalyzed methods that use lignin ionization (i.e., deprotonation) as a tool for lignin solubilization. A wide range of solvents, including alcohols [96-98], organic acids [99, 100], cyclic ethers [101, 102], short polyols [103], and ketones [104, 105], have been applied, either in combination with water and/or acids (mostly $\mathrm{HCl}, \mathrm{H}_{2} \mathrm{SO}_{4}$, or $\mathrm{H}_{3} \mathrm{PO}_{4}$ ) or in their pure form. Organosolv lignins typically possess a high purity and low molecular weight, and they are rich in phenolic hydroxyl groups, which make them soluble in a range of organic solvents [93].

Depending on the process characteristics, the final lignin structure can be extensively degraded or can show a partial preservation of the original functionalities, like the $\beta-\mathrm{O}-4$ bond [106]. If organic solvents are used in combination with acids or hot water, acid-catalyzed cleavage of hemicellulose, LCCs, and lignin ether bonds results in a soluble mixture of lignin- and hemicellulosederived products, next to a solid cellulose pulp. Afterwards, lignin is readily isolated from the liquid product mixture via precipitation [92-95]. An alternative strategy is the use of pure organic solvents without the addition of water or acids. Under such $\mathrm{pH}$-neutral conditions, the hydrolysis of both hemicellulose and cellulose is strongly impeded, while an extensive removal of lignin from the lignocellulose matrix can still be achieved, albeit at higher reaction temperatures. Solvolysis has been appointed to cause (partial) cleavage of LCCs and lignin ether bonds [107-110], yet additional investigations are required to clarify the underlying mechanisms [33, 98-100].

\section{Are Traditional Lignin Streams a Promising Feedstock for the Production of Chemicals?}

Lignin valorization towards chemicals constitutes an alluring biorefinery strategy. This is evidenced by the vast amount of lignin depolymerization studies, starting from 'traditional' lignin streams that are isolated by the lignocellulose fractionation methods discussed in Sect. 3. The production of lignin-derived chemicals, however, requires a multidisciplinary effort, not solely focusing on lignin depolymerization, but aligning all relevant variables between the initial feedstock choice and the target chemicals. Essentially, two complementary research domains can be defined: (1) fractionation and (2) depolymerization, wherein the isolated lignin forms the common element. To optimize the entire valorization chain, the output from both domains (i.e., isolated lignin from fractionation and depolymerized lignin from depolymerization) should be used as feedback mechanisms (see Fig. 5). 


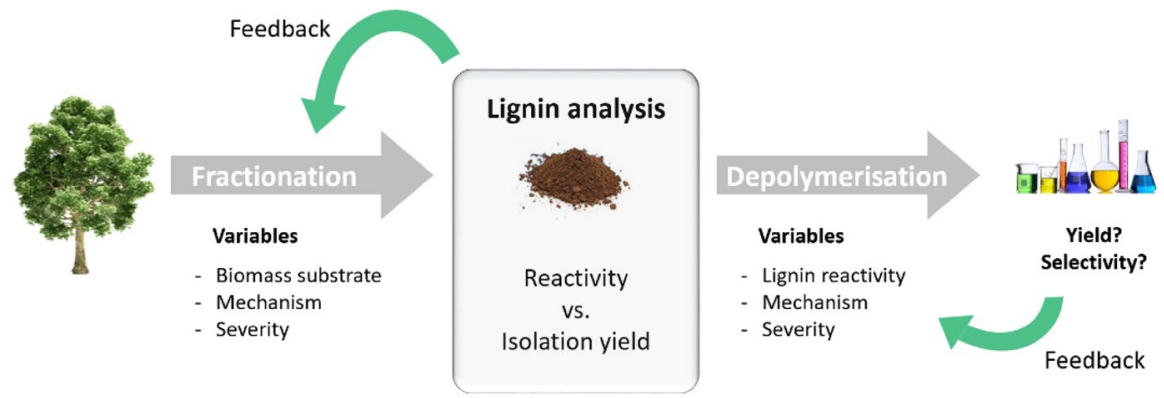

Fig. 5 Production of chemicals from isolated lignin requires reactive lignin isolates as well as effective depolymerization methods, both dependent on a multitude of variables. Robust analytical tools are imperative to allow a sensible interpretation of the product outcome from fractionation and depolymerization processes

\subsection{Considerations on the Isolation and Analysis of Lignin}

Obviously, the production of chemicals through lignin depolymerization is greatly influenced by the properties of the lignin substrate. Analysis of isolated lignins therefore embodies an important feedback mechanism that enables the optimization of existing fractionation methods. Aryl-ethers, mainly represented by $\beta-\mathrm{O}-4$ bonds, are the dominant inter-unit linkages in native lignin, but their abundance decreases significantly during most fractionation processes. Unfortunately, a reduced $\beta-\mathrm{O}-4$ content in the isolated lignin is typically linked to an impaired lignin reactivity and a lower phenolic monomer yield upon lignin depolymerization [12, 106, 111-113]. Recent studies, however, also showed that the correlation between the $\beta-\mathrm{O}-4$ content and the lignin reactivity is not fully conclusive, and that other factors like, for instance, the presence of impurities [e.g., sulfur, (earth) alkali metals, biomass degradation products] can influence the depolymerization efficiency as well $[106,111$, 112]. Nevertheless, the relative amount of $\beta-\mathrm{O}-4$ bonds, determined by $2 \mathrm{D}$ HSQC NMR [114, 115] or thioacidolysis [116], remains a useful and frequently applied measure to assess the reactivity of isolated lignins. Note that potential differences in the applied analytical protocols should always be considered when comparing the results of independent studies [117]. To avoid any ambiguity, designated characterization studies, using a fixed set of analytical techniques to compare the reactivity of isolated lignins, are indispensable.

General statements on the reactivity of lignin, obtained from different fractionation methods (e.g., kraft lignin vs. organosolv lignin), should be treated with caution, since the extent of $\beta-\mathrm{O}-4$ cleavage can vary significantly within the boundaries of a specific isolation method. Apart from the fractionation mechanism, the process severity and the lignocellulosic feedstock also greatly affect the reactivity of the isolated lignin. This was demonstrated by Barta et al. in a characterization study of 22 organosolv lignins, displaying a wide variation in $\beta-\mathrm{O}-4$ content, ranging from 2 to $62 \%$ [106]. Consequently, a more balanced discussion is required, encompassing all variables that contribute to the obtained lignin properties instead of only referring to the general term of the fractionation method. 
A final consideration is the difficulty to reconcile a high lignin reactivity with a high isolated lignin yield. Higher isolation yields usually require an increased process severity, which in turn has a negative impact on the lignin reactivity. Therefore, the isolation yield cannot be overlooked when striving for a maximal lignin reactivity, as it represents a crucial factor to optimize the yield to chemicals based on the original total amount lignin in the biomass feedstock [12, 118].

\subsection{Depolymerization of Traditional Lignin}

The large amount of existing depolymerization processes can be categorized into five main groups, based on their dominant cleavage mechanism (i.e., reductive, oxidative, acid/base, solvolytic, and thermal depolymerization). Each strategy leads to a characteristic product outcome and will be discussed below. It should, however, be stressed that comparing the depolymerization efficiency of different processes is never straightforward. A large variety of traditional lignin streams are available (see Sect. 3 and 4.1) and different procedures exist to analyze the reaction products after lignin depolymerization. Therefore, results can be described by multiple variables, while several definitions can be used for the same variable [117]. Nevertheless, for the production of chemicals from lignin, a specifically relevant measure is the monomer yield, defined as the wt $\%$ of lignin monomers, relative to the original weight of the lignin fraction in the biomass substrate. In addition, the monomer fraction ideally comprises a limited number of monomeric compounds, thus decreasing the product complexity and facilitating down-stream processing. For these reasons, both the monomer yield and the product selectivity within the monomer fraction will be discussed for each depolymerization strategy.

\subsubsection{Reductive Depolymerization}

Common to all reductive depolymerization processes is the use of a redox catalyst in the presence of a reducing agent. This combination allows the cleavage of arylether linkages through hydrogenolysis, thereby effectuating lignin depolymerization [119-121]. Other chemical reactions that frequently occur are the removal of oxygen via hydrodeoxygenation ( $\mathrm{HDO}$ ) and the saturation of $\mathrm{C}=\mathrm{C}$ double bonds, $\mathrm{C}=\mathrm{O}$ double bonds, or aromatic rings through hydrogenation. On the other hand, $\mathrm{C}-\mathrm{C}$ bond cleavage does normally not take place in reductive processes. Hydrogen is typically applied as the reductant, although the use of other reducing agents such as hydrosilanes has been demonstrated as well [122]. When hydrogen is supplied in the form of $\mathrm{H}_{2}$ gas, the process is typically called hydroprocessing. Catalytic transfer hydrogenation is an alternative option, which is based on hydrogen-donating solvents. Both hydroprocessing and catalytic transfer hydrogenation have been performed with noble metal (e.g., Pt/ $\left.\mathrm{Al}_{2} \mathrm{O}_{3}[29,111,112], \mathrm{Ru} / \mathrm{C}[123,124]\right)$ and base metal (e.g., NiMo [125, 126], $\mathrm{CuMgAlO}_{x}[127,128]$ ) catalysts.

In the case of hydroprocessing, a further distinction can be made between three process variants, each yielding characteristic lignin products. Mild hydroprocessing is usually performed at temperatures below $593 \mathrm{~K}$ in the presence of a solvent 
(e.g., water, alcohols, cyclic ethers, or solvent mixtures) [29, 111, 112, 129-131]. Under these conditions, the methoxy groups on the aromatic rings are mostly preserved, resulting in a relatively narrow product distribution, mainly containing methoxyphenolic monomers with a propanol- or alkyl-substituent at the para-position. Hydroprocessing at temperatures above $593 \mathrm{~K}$ can be denoted as harsh hydroprocessing and is characterized by a broader product spectrum, including mainly demethoxylated phenolic species, next to deoxygenated aromatics, alkanes, catechols, and methoxy-phenols [125, 126, 132-134]. Noticeably, harsh hydroprocessing can be performed in the absence of a solvent. Both mild and harsh hydroprocesses typically result in monomer yields below $20 \mathrm{wt} \%$ when starting from (partly) degraded traditional lignins, although higher yields have been reported. A third variant, called bifunctional hydroprocessing introduces an acidic catalyst in addition to the reductive system. This enables additional reactions such as hydrolysis and dehydration, resulting in a more extensive reduction of the lignin substrate towards alkanes at temperatures below $593 \mathrm{~K}$. To obtain a high alkane selectivity, sufficient acid strength and a good interaction between the acid and metal sites are both key [135-137]. Yields of up to $50 \mathrm{wt} \%$ and more towards $\mathrm{C}_{6}-\mathrm{C}_{18}$ alkanes have been reached, although these values represent both monomer and dimer products.

In liquid phase reforming, $\mathrm{H}_{2}$ gas is replaced by hydrogen-donating solvents, such as isopropanol, formic acid, tetralin, but also common alcohols like methanol and ethanol [29, 124, 127, 128, 138]. Advantages of this approach are a lower reactor pressure and reduced safety concerns. Note that the oxidation of the solvent as a result of hydrogen donation (e.g., isopropanol to acetone) implies an additional reduction-step, likely with $\mathrm{H}_{2}$ gas, to recuperate the solvent. The fate of oxidized solvent molecules is, nonetheless, scarcely described and therefore needs more attention in follow-up studies. A broad product spectrum is obtained, similar to that of harsh hydroprocesses, and monomer yields of up to $30 \mathrm{wt} \%$ are frequently observed. Hensen et al. reported even higher yields, reaching up to 60-86 wt\%, which was explained by the specific role of ethanol, functioning as capping agent and formaldehyde scavenger [127, 128]. This impedes lignin repolymerization and increases the mass of the lignin products due to extensive alkylation with ethanol.

\subsubsection{Oxidative Depolymerization}

During oxidative lignin depolymerization, an oxidant (e.g., $\mathrm{O}_{2}, \mathrm{H}_{2} \mathrm{O}_{2}$, nitrobenzene, metal oxides) is used to convert the lignin polymer into oxygenated low molecular weight compounds [139-141]. In contrast to reductive processing, where primarily ether bond are cleaved, oxidants also enable the scission of $\mathrm{C}-\mathrm{C}$ bonds. Most oxidation studies describe a selective $\mathrm{C}-\mathrm{C}$ cleavage of the aliphatic side-chain, resulting in the formation of methoxy-phenolic aldehydes, ketones, and acids. Alternatively, cleavage of the aromatic ring with formation of aliphatic (di)carboxylic acids can be targeted as well [139-143].

The most well-known example of oxidative lignin valorization through $\mathrm{C}-\mathrm{C}$ cleavage of the aliphatic side-chain is the production of the flavoring component vanillin (4-hydroxy-3-methoxybenzaldehyde) from sulphite liquor (see sulphite pulping in Sect. 3.1) [144, 145]. The process has been commercially practiced for 
over 80 years and was once the major route to vanillin in the world. Competition with vanillin synthesis from fossil resources, next to environmental concerns and the decreasing market volume of the sulphite pulping process, have now lowered the market share of lignin-derived vanillin to about $15 \%$ of the global production, leaving the Norwegian company Borregaard as sole remaining producer [144, 145]. The Borregaard process is performed in a concentrated aqueous $\mathrm{NaOH}$ solution and uses $\mathrm{O}_{2}$ (air) as the preferred oxidizing agent, as it is inexpensive, readily available, and converted to water upon reaction.

Recent studies on aerobic oxidative lignin depolymerization also often apply aqueous $\mathrm{NaOH}$ solutions. Nevertheless, other bases (e.g., KOH [146]), acids (e.g., acetic acid [147], $\mathrm{H}_{2} \mathrm{SO}$ [41] [46, 149], $\mathrm{H}_{3} \mathrm{PMo}_{12} \mathrm{O}_{40}$ [148, 149]), and solvents such as methanol [150] have been used as well. Although not essential, a large number of homogeneous and heterogeneous catalysts has been investigated to improve the attainable monomer yield [139-141]. The dominant use of alkaline media for aerobic oxidative lignin depolymerization is related to the fast ionization of phenolic groups at high $\mathrm{pH}$. Though the exact cleavage mechanism remains a subject of discussion, the formation of phenolate ions and their subsequent oxidation towards phenoxy-radicals is generally regarded as a crucial step to initiate $\mathrm{C}-\mathrm{C}$ bond cleavage $[140,142,151,152]$. Temperatures of 393-463 K with a (partial) oxygen pressure of 2-15 bar are commonly applied, with the primary products being $p$-hydroxybenzaldehyde, vanillin, and syringaldehyde, next to their acid- and aceto-analogues. These monomer products are prone to secondary (repolymerization) reactions under the applied oxidative conditions, resulting in phenolic monomer yields of around $10 \%$ [153, 154]. Interestingly, short reaction times at high temperatures, using a flow-through setup, can be applied to minimize product degradation and increase the phenolic monomer yield [155].

An opposite strategy is to target the further oxidative conversion of unstable phenolic products. Cleavage of the aromatic ring can be favored by increasing the reaction time, the reaction temperature, the $\mathrm{O}_{2}$ partial pressure, or by applying a stronger oxidant such as $\mathrm{H}_{2} \mathrm{O}_{2}$. This results in a selective production of aliphatic (di)carboxylic acids, mainly represented by formic, acetic, oxalic, malonic, and/or succinic acid. The ratio in which each acid is formed strongly depends on the process characteristics. A variety of temperatures (333-498 K), pH conditions (acid [156, 157], neutral [158], base [143, 156]), and oxidants $\left(\mathrm{O}_{2}\right.$ [116] and $\mathrm{H}_{2} \mathrm{O}$ [156-158]) have been applied, resulting in a wide range of total monomer yields from 11 to $56 \mathrm{wt} \%$.

\subsubsection{Acid- or Base-Catalyzed Depolymerization}

As mentioned previously, acid or base catalysts are often added during reductive or oxidative depolymerization processes as a way to further improve the yield or selectivity of the monomeric products. However, a vast amount of catalytic studies also demonstrated the applicability of homogeneous and heterogeneous acids or bases as catalysts for the depolymerization of lignin in a redox-neutral environment. Typically, the absence of a redox driving force is counteracted by stronger catalysts and/or higher process temperatures (typically $>513 \mathrm{~K}$ ) [159-165]. No hydrogenation or cleavage of aromatic rings is observed, resulting primarily in a set of 
methoxy-phenolic products without a side-chain group or with an aldehyde-, aceto-, acid-, alkene-, or alkane-functionality at the para-position. Both in acid and basecatalyzed depolymerization, a shift in the product selectivity towards catechols and alkyl-catechols has been observed at increasing temperatures [161-164]. Most studies report monomer yields below $20 \mathrm{wt} \%$, although a few acid-catalyzed depolymerization studies have reported higher phenolic monomer yields between 20 and 60 wt $\%[164,165]$.

As discussed in Sect. 3, lignin is prone to repolymerization reactions in the presence of acid or base catalysts. The repolymerization products have a low solubility in water and are easily converted to chars [160]. A possible solution is the use of (aqueous) organic solvents instead of pure water in order to improve the solubility of the lignin products in the reaction medium. For instance, Hensen et al. showed a doubling in monomer yield (from 6 to $13 \mathrm{wt} \%$ ) when switching from water to ethanol as the reaction solvent during depolymerization of wheat straw soda lignin with a Lewis acid Cu-acetate catalyst [160]. Superior monomer yields with organic solvents, compared to reactions in water, were also demonstrated for the acid-catalyzed depolymerization of softwood kraft lignin with metal chlorides [164], as well as for the base-catalyzed depolymerization of pine ethanosolv lignin with $\mathrm{MgO}$ [159].

\subsubsection{Solvolytic Depolymerization}

Without oxidants, reductants, and acid/base additives, solvolytic depolymerization processes benefit from their simplicity regarding downstream product isolation and the redundancy of catalyst recovery. Water, organic solvents, and mixtures thereof have been used as reaction media at temperatures in the range of 523-723 K [160, 164, 166-170]. A fairly broad product distribution is obtained, consisting of (methoxy-)phenols with oxygenated and unsaturated side chains for reactions at the lower end of the temperature spectrum, while shifting towards unsubstituted and alkylated (methoxy-)phenols and catechols at higher temperatures or with higher water-tosolvent ratios [166-168]. As solvolytic depolymerization processes often function as the blank run in catalytic studies, a comparison is easily made. Typically, noncatalyzed processes reach inferior monomer yields compared to their corresponding catalytic process, and usually do not surpass $10 \mathrm{wt} \%$. However, higher monomer yields are sometimes reported, for instance reaching $22 \mathrm{wt} \%$ from softwood kraft lignin in water at $537 \mathrm{~K}$ [169] or $24 \mathrm{wt} \%$ from an organosolv lignin (extracted from corncob residue) in tetrahydrofuran at $573 \mathrm{~K}$ [170].

\subsubsection{Thermal Depolymerization Through Fast-Pyrolysis}

In fast-pyrolysis (FP), lignin (or biomass) is rapidly heated to high temperatures of 673-1073 $\mathrm{K}$ in the absence of oxygen [171-173]. Under these conditions, vapors are formed next to a solid carbon-enriched char. After removal of the vapors from the heating zone, they are partially condensed into a liquid oil while the remaining fraction is collected in the form of gasses. When targeting the production of chemicals from lignin, a maximization of the liquid fraction is wanted, as it contains the lignin-derived monomers. Higher oil- and monomer yields are normally obtained at temperatures between 
673 and $923 \mathrm{~K}$ for short vapor residence times (in the order of seconds) [171]. The yields can be further increased by the addition of a catalyst, at which the process is thus called catalytic fast-pyrolysis (CFP). The catalyst serves a dual role, as it (1) stabilizes reactive intermediates to avoid excessive charring, and (2) increases the product selectivity [172]. The latter is especially clear in the case of acid zeolites, which can be used to drastically improve the selectivity towards deoxygenated aromatics like benzene, toluene, and xylene [174-179]. As demonstrated for a range of H-ZSM-5 catalysts, the lower the Si/Al ratio, the higher the acid density and the higher the yield of deoxygenated aromatics [176]. Moreover, Triantafyllidis et al. investigated the influence of porosity and external surface area of H-ZSM-5 on the selectivity towards monophenolics or deoxygenated aromatics [180]. Next to H-ZSM-5, other zeolites (sometimes loaded with metals) and oxides have also been applied in CFP [181-184]. During noncatalytic fast-pyrolysis or when the applied catalyst has a low acidity, the product selectivity shifts from deoxygenated products to methoxy-phenolic and catechol products, substituted with oxygenated, unsaturated, or saturated side chains. Overall, most studies on FP and CFP report large numbers of monomer products with total monomer yields below $10 \%$, although higher selectivities and yields of up to $40 \%$ have been sporadically observed with CFP [176, 180, 185].

\subsection{Closing Remarks on Traditional Lignin Valorization}

Traditional lignin valorization is defined here as a two-step lignin isolation-depolymerization approach in which no special attention is given to the fate of the lignin structure during isolation (i.e., fractionation). This approach comes forth from the current dominance of carbohydrate-oriented biorefineries in which a maximal valorization of the carbohydrates is the primary objective. A large side-stream of isolated lignin is obtained this way, which can serve as a substrate for depolymerization towards chemicals. However, as discussed in Sect. 3, the native lignin structure is prone to repolymerization and degradation reactions during the fractionation process, hereby impeding downstream depolymerization. Although promising results have been reported (see Sect. 4), most studies clearly demonstrated the recalcitrant nature of traditional lignins, reaching monomer yields below $20 \mathrm{wt} \%$, often in combination with a broad spectrum of lignin monomer products. In order to address the issue of lignin condensation, alternative strategies for lignin valorization have emerged [186], either (1) targeting the isolation of native-like lignin, in which the original reactivity is maximally preserved or (2) enabling lignin depolymerization to stable monomeric products during lignocellulose processing (see Fig. 6). Both strategies will be discussed in separate sections (Sects. 5, 6), while providing an overview of the most promising examples and their main advantages and disadvantages. 


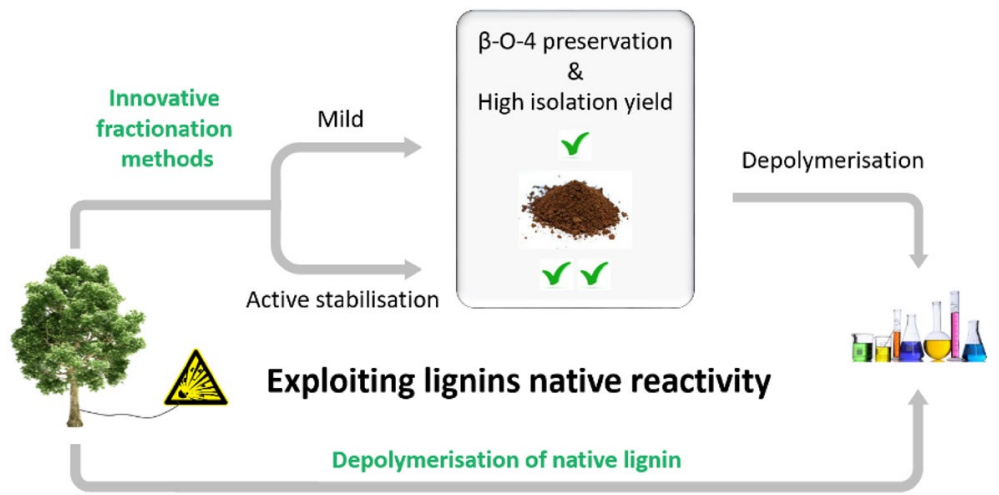

Fig. 6 Lignin valorization to chemicals should exploit the reactive structure of native lignin. Two major routes exist, either targeting lignin isolation with minimal structural alterations (Sect. 5) or directly depolymerizing native lignin to stable monomeric products during lignocellulose processing (Sect. 6)

\section{Innovative Lignin Streams: Preserving $\beta-0-4$ Bonds During Fractionation}

Compared to most isolated lignins, the native lignin structure is more susceptible to depolymerization as a result of its higher ether-bond content and reduced degree of $\mathrm{C}-\mathrm{C}$ crosslinking. A valid strategy therefore is to isolate lignin from lignocellulosic feedstocks with minimal alteration of its original chemical structural features. This way, the obtained lignin isolate forms a more reactive substrate for further conversions to chemicals. Despite lignin's strong tendency towards condensation, several fractionation methods have achieved the isolation of native-like lignin, especially with respect to the preservation of $\beta-\mathrm{O}-4$ bonds. To favor lignin isolation over lignin condensation, most of these innovative methods apply mild process conditions, for example by improving the lignin solvating power of the reaction medium. Alternatively, active stabilization mechanisms were introduced recently, allowing a higher process severity and higher isolation yields of native-like lignin.

\subsection{Mild Fractionation: Passive Approach}

\subsubsection{Ammonia}

The use of liquid ammonia as a swelling agent for cellulose and as a suitable solvent for lignin solubilization has been known for over 60 years [187, 188]. Several ammonia-based processes are particularly relevant in the context of mild fractionation on herbaceous crops, where high degrees of structural preservation have been achieved in the isolated lignin. Note, however, that a good preservation of $\beta-\mathrm{O}-4$ bonds often goes hand in hand with low to intermediate lignin extraction yields (circa 50\%) [111, 189-191]. Moreover, small quantities of nitrogen are incorporated in the lignin products in the form of amides $[189,192]$. 
Ammonia fiber expansion or AFEX is probably the most recognized ammoniabased method and starts by contacting wet biomass with ammonia. Temperatures close to the critical temperature of ammonia (405 K) are typically applied, resulting in high autogenous pressures ( $>100$ bar) [193-195]. Alongside other reactions, the lignin polymer is partially solubilized after hydrolysis and ammonolysis of LCCs and to a minor extent lignin ether bonds [194, 196]. Following an explosive pressure release, ammonia is briskly evaporated, opening up the biomass structure while redistributing lignin [194]. As such, AFEX is not a fractionation method, but simply induces physicochemical alterations of the lignocellulose matrix, hereby enhancing its susceptibility towards lignin extraction. By using organic or alkaline extraction solvents, $50-65 \%$ of the native lignin in herbaceous crops can be extracted, mainly in the form of oligomeric fragments with a well-preserved amount of $\beta-\mathrm{O}-4$ bonds [111, 190, 194].

A second method is called anhydrous ammonia pretreatment (AAP) and differs from AFEX by the required low moisture content of the lignocellulosic feedstock and the absence of an explosive pressure release [191, 192, 197]. Without this pressure drop, the lignin-containing ammonia solution can be easily separated from the solid carbohydrate fraction. This process is also often referred to as extractive ammonia pretreatment (EAP). However, relatively low extraction yields of circa $45 \%$ have been obtained from corn stover [191, 197]. Alternatively, a controlled evaporation of ammonia, followed by an alkaline extraction results in higher isolation yields, up to $65 \%$ [192]. The low moisture content of the substrate is required to allow an intense interaction between crystalline cellulose domains and ammonia. This alters the crystalline structure of cellulose from its native $C_{I}$ form into the $C_{I I I}$ polymorph, making it more susceptible towards enzymatic hydrolysis [198].

Finally, higher lignin extraction yields, up to $85 \%$ from corn stover, have been obtained by performing a flow-through lignin extraction from lignocellulose with aqueous ammonia [199-201]. This process is called ammonia recycled percolation (ARP), as it continuously recovers and reuses the ammonia through evaporation. ARP has also been performed on hardwoods, reaching extraction yields of up to $63 \%[189,202]$. After precipitation from the reaction mixture, a rather low isolated lignin yield of $31 \%$ was obtained by Jackson et al., yet showing a good retention of $\beta-\mathrm{O}-4$ bonds $[111,189]$.

\subsubsection{Ionic Liquids}

Ionic liquids (IL) are known for their excellent solubilizing capacity, which can be tailored to the envisioned application by a careful selection of the anion and cation [67, 203-205]. For the effective isolation of native-like lignin from lignocellulose, the ionosolv process is a promising method. In analogy to traditional (aqueous) organosolv fractionation, a selective solubilization of lignin and hemicellulose is targeted, while retaining cellulose as a solid product. However, the use of ILs allows to work at lower reaction temperatures $(<433 \mathrm{~K})$ and at atmospheric pressure, which in turn reduces structural alterations in the lignin polymer. As a result, ionosolv lignins retain a significant amount of the original $\beta-\mathrm{O}-4$ bonds, although the extent of $\beta-\mathrm{O}-4$ bond cleavage is strongly dependent on the IL and the process 
conditions [112, 206, 207]. Despite their interesting physico-chemical properties, several challenges need to be addressed before an IL can be labeled as a competitive green solvent. For instance, the use of halogenated anions (e.g., $\mathrm{PF}^{6-}, \mathrm{BF}^{4-}$ ) and organic cations (e.g., substituted imidazolium) in many common ILs, results in a high cost of components [203, 206]. This in turn requires a long-term stability of the IL under the applied reaction conditions of the biorefinery process, as well as an efficient isolation procedure, to allow multiple recycling of the IL. Moreover, a high purity is required as low amounts of IL degradation products or biomass components can severely influence the properties and the dissolution performance of the IL [205]. Finally, the development of environmentally friendly synthesis routes (e.g., deep eutectic solvents [208]) and a better understanding of the toxicity and biodegradability of ILs are important criteria to advance their applicability in the biorefinery [203, 205, 206, 209].

\subsubsection{Flow-Through Reactor Setups for Acid Hydrolysis}

Compared to batch-mode dilute acid hydrolysis (see DAH in Sect. 3.2), a flowthrough reactor setup (FT-DAH) is much more suited to combine high temperatures and short residence times. This way, reactive carbohydrate and lignin intermediates can be removed from the heating zone before degradation occurs [156, 210, 211]. In contrast to the solid lignin residue obtained upon batch mode processing, FT-DAH mainly produces soluble and less degraded oligomers, which can be recovered from the product solution via precipitation. Successful depolymerization of the isolated lignin precipitate clearly indicates a partial preservation of $\beta-\mathrm{O}-4$ bonds $[156,211]$.

Two related flow-through processes are dilute acid pretreatment (FT-DAP) and hot water pretreatment (FT-HWP), which apply milder process conditions to target a selective solubilization of hemicellulose and lignin, while retaining cellulose as a solid product $[212,213]$. FT-DAP uses lower acid concentrations or temperatures compared to FT-DAH, while FT-HWP represents an autocatalytic process that is based on the acidic properties of hot water in combination with organic acids (e.g., acetic acid), originating from the lignocellulosic substrate [72, 73, 212, 213]. The relatively mild process conditions in both methods result in highly oxygenated low molecular weight lignin products (mainly oligomers), which are proposed to possess a significant part of the original $\beta-\mathrm{O}-4$ interunit linkages [156, 190, 211], yet additional investigations are required. The high solubility of the lignin-derived product fraction in the hydrolysate solution, however, hampers an effective precipitation and isolation of the lignin fraction [213].

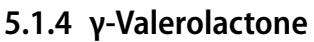

As mentioned in Sect. 3.3 on organosolv fractionation, the extent of $\beta-\mathrm{O}-4$ bond cleavage varies significantly with different solvents and process conditions [106]. A remarkably mild organosolv fractionation was reported by Dumesic et al., using an $80 / 20 \mathrm{wt} \%$ mixture of $\gamma$-valerolactone (GVL) and water with a low concentration of $\mathrm{H}_{2} \mathrm{SO}_{4}(1.5 \mathrm{wt} \%)$ [123]. The use of the polar aprotic solvent GVL promotes the disruption of the lignocellulose matrix [214-218] and allows an effective solubilization 
of lignin and hemicellulose [123]. The yield of extracted lignin from corn stover reached $75 \%$ at a reaction temperature of $423 \mathrm{~K}$. After precipitation, the isolated lignin was analyzed by 2D HSQC NMR, showing great structural similarities with native lignin [123]. Moreover, the preservation of $\beta-\mathrm{O}-4$ bonds, observed with NMR, was further corroborated by high monomer yields of up to $48 \%$, obtained upon bifunctional hydroprocessing of the lignin precipitate with $\mathrm{Ru} / \mathrm{C}, \mathrm{H}_{3} \mathrm{PO}_{4}$, and $\mathrm{H}_{2}$ [123].

\subsubsection{Mechanical Pretreatment}

Applying mechanical stress to open up the lignocellulose structure is another strategy to isolate lignin with minimal structural alterations compared to native lignin [219-222]. However, these procedures are lengthy and usually reach limited lignin isolation yields. As a result, this approach is primarily relevant in analytical lignin studies where a maximal preservation of the native lignin structure is the main requirement and no restrictions exist with regard to process costs and efficiency. Milled wood lignin (MWL) for instance, is obtained by ball-milling a lignocellulosic substrate for several days, followed by lignin extraction with an aqueous organic solvent [220-222]. The yield of the isolated native-like lignin is generally below $35 \%$ [223]. Instead of direct lignin extraction, mechanical pretreatments can also be followed by an enzymatic hydrolysis step, using cellulolytic enzymes. Here, the carbohydrates are converted into soluble mono- and oligosaccharides, while a solid residue is obtained, containing a mixture of lignin, residual carbohydrates, proteins and ashes. Lignin can be extracted from this solid residue and subsequently precipitated, after which it is denominated as cellulolytic enzyme lignin (CEL) [223-225]. Again, a high preservation of $\beta-\mathrm{O}-4$ bonds and a rather low lignin yield $(<35 \%)$ is obtained [223, 226]. Lignin isolation can be improved by performing an additional acid hydrolysis step on the solid residue obtained upon enzymatic hydrolysis [226, 227]. This results in the cleavage of lignin-carbohydrate complexes and enables a more extensive solubilization of lignin. After precipitation, a $65 \%$ yield of enzymatic mild acidolysis lignin (EMAL) can be obtained [223, 226].

\subsection{Chemical Stabilization During Fractionation: Active Approach}

A general observation with respect to mild fractionation processes is the undesirable trade-off between the lignin isolation yield and the preservation of $\beta-\mathrm{O}-4$ bonds in the isolated lignin. Although the methods discussed in Sect. 5.1 enable the production of reactive lignins, isolation yields are limited due to the mild process conditions. On the other hand, attempts to improve the isolation yield by increasing the process severity are often linked with increased lignin degradation [106, 203]. A promising advancement here is the use of active stabilization mechanisms that prevent the formation of reactive intermediates during fractionation. Ideally, $\beta-\mathrm{O}-4$ bonds can be preserved under more severe process conditions, in turn leading to higher lignin isolation yields. 
Luterbacher et al. was the first to demonstrate the success of this approach [79]. Related to organosolv processing, the method uses an acidified aqueous dioxane reaction mixture to extract lignin from the lignocellulosic feedstock (i.e., beech wood). With this method, high lignin extraction yields of up to $80 \%$ can be obtained at low temperatures of 353-373 K [79]. The innovative aspect lies in the addition of formaldehyde (FA), which undergoes acid-catalyzed condensation with the $\alpha$ - and $\gamma$-OH side-chain groups, hereby forming 1,3-dioxane structures (see Fig. 7) [79]. This acetal is relatively stable under the applied conditions and prevents the formation of reactive carbenium ions, the key intermediate in acid-catalyzed depolymerization and repolymerization reactions. A second stabilization mechanism is the blocking of reactive meta-positions [78] on the aromatic ring, through electrophilic substitution with FA. This way, $m$-hydroxymethyl groups are formed, though without the formation of recalcitrant methylene bridges [228].

The excellent structural integrity of the FA-stabilized lignin was demonstrated by a subsequent reductive depolymerization with a $\mathrm{Ru} / \mathrm{C}$ catalyst at $523 \mathrm{~K}$ in methanol. A lignin monomer yield of $47 \%$, based on the total lignin in beech wood, was realized, which is around the theoretical maximum [79]. In contrast, when fractionation was performed in the absence of FA, the subsequent depolymerization of the isolated lignin only resulted in a 7\% monomer yield. Furthermore, a decent product selectivity towards ethyl- and propyl-substituted guaiacol and syringol can be obtained. After reductive depolymerization, the hydroxymethyl groups at the meta-position are retained in the form of methyl groups on the aromatic ring, while FA incorporated in the 1,3-dioxane structure is converted to methane. Note that this strategy implies the consumption of formaldehyde and also lowers the product selectivity by the introduction of additional methyl side chains. Interestingly, aromatic alkylation can be excluded by utilizing other aldehydes than FA, such as acetaldehyde and propionaldehyde [229].

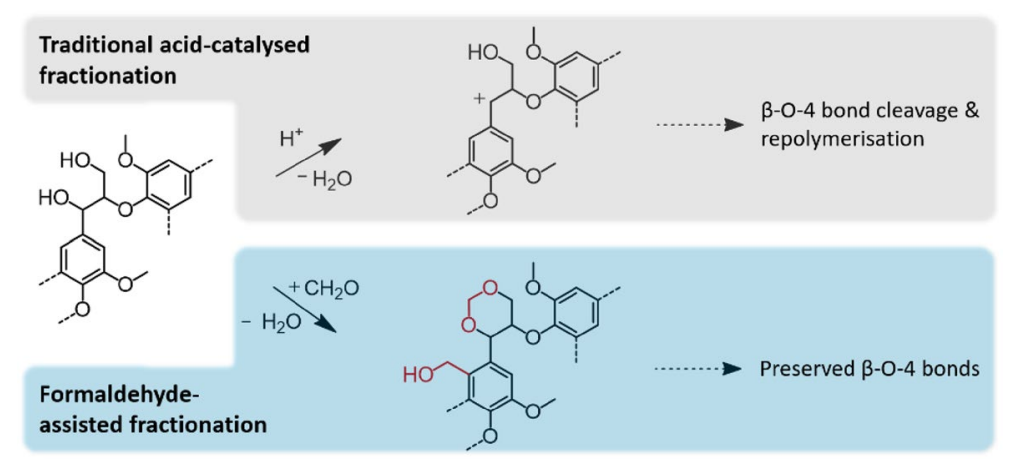

Fig. 7 Lignin stabilization during formaldehyde-assisted fractionation. The formation of 1,3-dioxane structures prevents the formation of reactive carbenium ions (see also Sect. 3.2) while hydroxymethyl groups block reactive meta-positions [79] 


\section{Depolymerization of Native Lignin to Stable Monomers}

Instead of targeting the high-yield isolation of native-like lignin (Sect. 5), a complementary valorization approach is to instantly convert native lignin to stable lignin monomers during lignocellulose processing. The key aspect is to provide a process environment in which lignin depolymerization can be performed without the detrimental consequences of lignin repolymerization. Reductive depolymerization-stabilization of native lignin has been investigated most frequently, though other methods exist and are applicable as well.

\subsection{Reductive Catalytic Fractionation (RCF)}

Hydrogenolysis of native lignin through redox catalysis under reductive conditions was first conveyed in literature by Hibbert, Pepper, and coworkers around 70 years ago [230-233]. Their research efforts were primarily focused on the analytically challenging elucidation of the lignin structures in several lignocellulosic species (e.g., maple, spruce, wheat straw), but also demonstrated the selective production of phenolic monomers with a preserved structure, resembling the original lignin building blocks. These observations were later explained by solvolytic reactions and a reductive catalytic depolymerization-stabilization of lignin (intermediates) [107, 234-236]. Nevertheless, the potential of this approach for the production of ligninderived chemicals in a lignocellulosic biorefinery was recognized only recently. This lignin-first type of biorefinery strategy is referred to here as "reductive catalytic fractionation (RCF)", but is also known under the name "catalytic upstream biorefining (CUB)" [237-239].

In 2008, Yan et al. was one of the first to report near theoretical monomer yields (up to $46 \%$ ) by processing birch sawdust in a dioxane:water (50:50 vol\%) mixture in the presence of a $\mathrm{Pt} / \mathrm{C}$ catalyst and $4 \mathrm{MPa} \mathrm{H}_{2}$-gas at $473 \mathrm{~K}$ for $4 \mathrm{~h}$ [240]. Similar results were obtained by Song et al. (2013), who acquired phenolic monomer yields of around 50\% from birch wood in pure methanol [234]. Interestingly, the solvent methanol served as the hydrogen donor for reductive depolymerization-stabilization. An inexpensive base-metal Ni/C catalyst was applied, demonstrating an $89 \%$ selectivity towards propyl-substituted guaiacol and syringol (see Fig. 8). Instigated by such promising results, the scientific field of RCF processing has strongly expanded the last few years [241], leading to several fundamental and technological advancements.

Understanding the relation between the applied feedstock and the product outcome is a vital aspect in any biorefinery. Studies have illustrated the positive correlation between the amount of syringyl units (S-units) and the $\beta-\mathrm{O}-4$ content within the original lignin structure of different feedstocks [42, 43]. This in turn has a direct impact on the attainable lignin monomer yield from RCF. As a result, RCF of hardwoods (up to $80 \% \mathrm{~S}$-content) generates the highest yields of phenolic monomers (40-55\%), in contrast to the monomer yields from softwoods (>95\% G-content), which usually do not surpass $30 \%$ [46, 234, 240-244]. RCF of herbaceous crops 


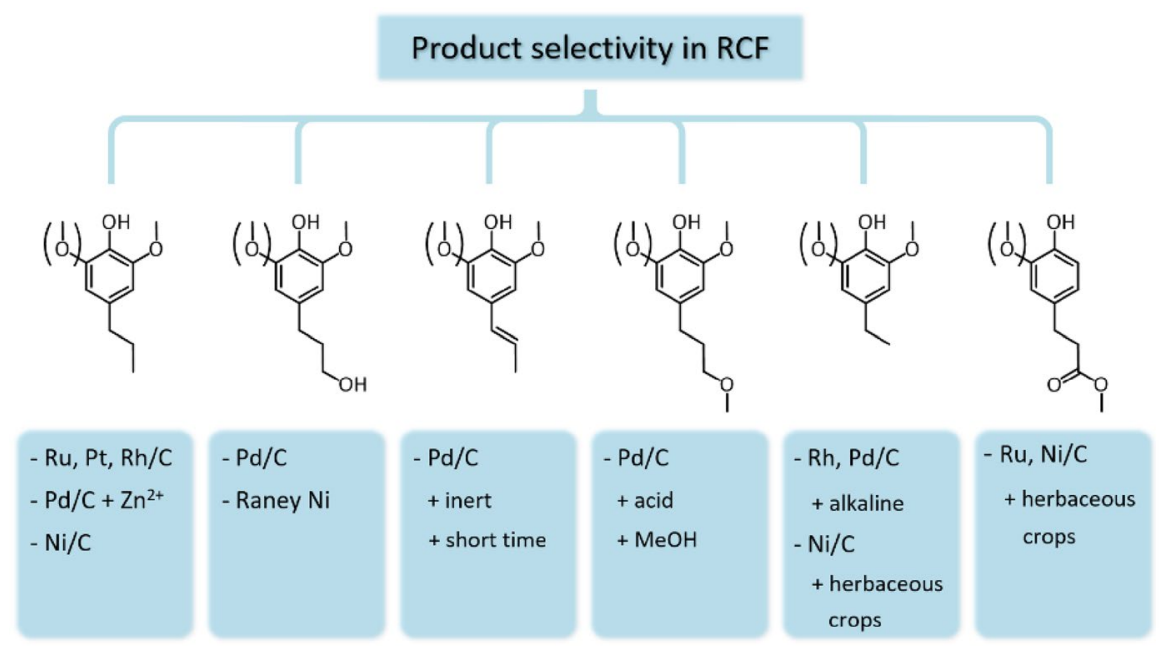

Fig. 8 Overview of the phenolic monomer products that can be selectively obtained from reductive catalytic fractionation (RCF) under specified catalytic conditions (and feedstock)

$(5 \% \mathrm{H}, 65 \% \mathrm{G}, 30 \% \mathrm{~S})$ typically leads to intermediate monomer yields of $25-40 \%$, though yields of over $60 \%$ have been reported [46, 237, 245]. Consequently, most RCF studies have been performed on hardwoods. Notwithstanding, the very high selectivity to guaiacyl compounds from softwoods or the unique feature of sidechain ester or acid groups from herbaceous crops (see Fig. 8) justify their use for $\mathrm{RCF}$ as well.

Next to the feedstock, the solvent also plays a decisive role during RCF. First of all, the fractionation efficiency (i.e., delignification versus carbohydrate pulp retention) is strongly dependent on the polarity and the lignin solvating power of the solvent (or solvent mixture) [221, 232, 233]. The solvent should hence be carefully selected and optimized in relation to other process parameters, like the reaction temperature and time [234, 246, 247]. Interestingly, acid additives (e.g., $\mathrm{H}_{3} \mathrm{PO}_{4}[238$, 240], $\left.\mathrm{Yb}(\mathrm{OTf})_{3}[248,249]\right)$ can be used to further tune the fractionation efficiency while reducing the process severity. Moreover, several solvents, such as isopropanol, methanol, and ethanol, have been applied as a hydrogen donor in RCF, thus eliminating the direct need for external $\mathrm{H}_{2}$ [234, 244]. Alternatively, other components (e.g., formic acid), released during the fractionation process, have been appointed as effective hydrogen donors [242, 250]. Finally, an active participation of the solvent in the (partial) cleavage of lignin carbohydrate complexes and/or $\beta-\mathrm{O}-4$ bonds has been suggested [234, 242, 243, 245]. It was shown that under specific conditions (e.g., $\mathrm{MeOH}$ at $523 \mathrm{~K}$ and $12 \mathrm{MPa}$ ) lignin solubilization and depolymerization occur predominantly via solvolytic (instead of catalytic) mechanisms [107]. In this case, catalytic action is solely required to stabilize lignin intermediates in solution through hydrogenation. Consequently, no physical contact between the heterogeneous catalyst and the solid lignocellulosic substrate is required during RCF, as demonstrated by the successful use of a catalyst basket [107]. This also facilitates the previously 
challenging separation between the solid catalyst and the carbohydrate pulp after $\mathrm{RCF}$, and opens up new opportunities in future reactor design (e.g., Carberry reactors, flow-through fixed-bed catalytic reactors) and scale-up initiatives. Interestingly, the above findings were corroborated recently by two independent research groups, successfully demonstrating RCF in a flow-through reactor. A fixed bed containing lignocellulose feedstock was placed in front of a fixed catalyst bed. At elevated temperature, a flow of methanol extracts lignin intermediates from the biomass bed, which are subsequently forced through the catalyst bed. Liquid sampling before and after the catalyst bed therefore enabled the isolation of solvolytic and catalytic processes [235, 236, 251].

A final key feature in the RCF process is the catalytic system. Apart from effectuating high lignin monomer yields through reductive stabilization, the catalyst also functions as a tool to tune the product selectivity, especially with regard to the functionalities on the para-substituted side chain (see Fig. 8). As mentioned previously, a high selectivity to propyl-substituted phenolic monomers can be obtained with a $\mathrm{Ni} / \mathrm{C}$ catalyst and methanol as the hydrogen-donating solvent. Similar results were obtained with $\mathrm{Ru} / \mathrm{C}, \mathrm{Pt} / \mathrm{C}$, and $\mathrm{Rh} / \mathrm{C}$ catalysts or with a synergistic $\mathrm{Pd} / \mathrm{C}$ and $\mathrm{Zn}^{2+}$ catalytic system, all in the presence of pressurized $\mathrm{H}_{2}$ [46, 240, 243]. These catalytic systems are capable of removing $\gamma-\mathrm{OH}$ groups through hydrogenolysis or tandem dehydration/hydrogenation. Other catalysts, such as $\mathrm{Pd} / \mathrm{C}$ and Raney $\mathrm{Ni}$, selectively retain the $\gamma-\mathrm{OH}$ functionality and reach high selectivities to propanol-substituted monomers [244, 252, 253]. Alternatively, Galkin et al. reported a high selectivity to propenyl-substituted guaiacol and syringol under inert atmosphere, using an $\mathrm{H}_{2}$-activated $\mathrm{Pd} / \mathrm{C}$ catalyst at a short reaction time of $1 \mathrm{~h}$ [242]. Moreover, $\mathrm{Pd} / \mathrm{C}$ in combination with $\mathrm{Al}(\mathrm{OTf})_{3}$ acid results in methoxypropyl-substituted phenolic monomers, formed by the acid-catalyzed etherification of $\gamma-\mathrm{OH}$ groups with methanol, which is used as the solvent [248]. Finally, also ethyl-substituted monomers $\left(\mathrm{C}_{2}\right)$ can be selectively obtained from RCF, for instance through decarboxylation/hydrogenation of acid or ester side chains, present in the monomers from RCF with herbaceous crops (see also previous paragraph on the influence of the lignocellulosic substrate) [237]. Another route is to perform RCF in alkaline media, leading to the base-catalyzed release of formaldehyde from quinone methide intermediates (see Fig. 3). The resulting enol-ether is then further converted to ethyl-substituted monomers through subsequent $\beta-\mathrm{O}-4$ bond cleavage and hydrogenation [233, 238].

\subsection{Reductive One-Pot Processing}

Reductive processing of lignocellulosic biomass does not necessarily cause fractionation into a lignin oil and a carbohydrate pulp. Recently, so-called one-pot processes have been disclosed that target the transformation of the complete lignocellulose matrix into soluble low molecular weight products. These processes are characterized by a higher process severity in terms of solvent, acidity, and/or temperature compared to RCF. In short, reductive one-pot processes and RCF processes both benefit in a similar way from the reactivity of native lignin as well as the reductive 
stabilization of lignin intermediates, but differ with regard to the fate of the carbohydrate fraction.

$\mathrm{Li}$ et al. investigated the one-pot conversion of birch wood with a $\mathrm{Ni}-\mathrm{W}_{2} \mathrm{C} / \mathrm{AC}$ catalyst in water at $508 \mathrm{~K}$ and $6 \mathrm{MPa} \mathrm{H}_{2}$. Lignin monomer yields of over $35 \%$ were combined with a $70 \%$ yield of sugar-derived diols, mainly represented by ethylene glycol and propylene glycol [254]. The same process with methanol as the solvent (i.e., typical RCF conditions) gave a phenolic monomer yield of $47 \%$ (around the theoretical maximum) without carbohydrate conversion to diols. Note that in this specific process, the acidity of water at high temperature is required to realize effective carbohydrate hydrolysis as a first step to $\mathrm{C}_{2}-\mathrm{C}_{4}$ diols [254]. However, (pure) organic solvents have been successfully applied as well for one-pot processing. Ford et al. applied supercritical methanol (573-593 K at 160-220 bar) in the presence of a copper-doped porous metal oxide to produce substituted cyclohexyl alcohols and ethers from lignin and acyclic $\mathrm{C}_{2}-\mathrm{C}_{6}$ alcohols and ethers from the carbohydrate fraction [255, 256]. Alternatively, specific acid-redox catalytic systems (e.g., TSA + ht$\mathrm{Ru} / \mathrm{C}$ [257, 258], $\mathrm{Pt} / \mathrm{NbOPO}_{4}$ [259]) achieve the production of gasoline-range alkanes via extensive depolymerization and hydrodeoxygenation of both lignin and (hemi)cellulose components at relatively mild temperatures of 463-493 K. Interestingly, the alkane product mixture is likely suitable for fuel applications without additional separation steps. In other cases, the cost-efficiency of a one-pot process should always be considered against the costs, related to a potentially more difficult product separation.

\subsection{Oxidative Catalytic Fractionation (OCF)}

As discussed in Sect. 4.2 on the oxidative depolymerization of isolated lignin, oxidants are known to enable the cleavage of $\mathrm{C}-\mathrm{C}$ bonds. Nevertheless, most oxidation studies yield low amounts of aromatic monomers (typically $<15 \%$ ) from isolated lignin [153, 154]. Similar to RCF, oxidative catalytic fractionation (OCF) is performed directly on lignocellulosic substrates, hereby exploiting the reactivity of native lignin to improve the attainable monomer yield. The potential of this approach has already been indicated in the 1930s, when nitrobenzene and later $\mathrm{CuO}$ were used as oxidants to depolymerize lignin for compositional analysis [260, 261]. Both methods (i.e., nitrobenzene and $\mathrm{CuO}$ oxidation) were compared by Pepper et al., reaching monomer yields of circa $20 \%$ from spruce wood and $40 \%$ from aspen wood upon reaction at $453 \mathrm{~K}$ for $2 \mathrm{~h}$ in a concentrated $2 \mathrm{M} \mathrm{NaOH}$ solution [261]. According to the guaiacyl/syringyl ratio of the lignocellulosic feedstock, either vanillin (spruce) or syringaldehyde (aspen) was the major monomer product. More recently, Tarabanko et al. successfully applied $\mathrm{O}_{2}$ as an inexpensive and environmentally benign oxidant during birch processing, using a homogeneous $\mathrm{Cu}(\mathrm{OH})_{2}$ catalyst in a $2.5 \mathrm{M}$ $\mathrm{NaOH}$ solution at $443 \mathrm{~K}$ for $25 \mathrm{~min}$ [262]. A combined monomer yield of $43 \%$ was obtained for the aldehyde-substituted monomers vanillin (13\%) and syringaldehyde $(30 \%)[262,263]$. Noticeably, in the absence of $\mathrm{Cu}(\mathrm{OH})_{2}$, the selective production of vanillin and syringaldehyde decreased by half. Next to the soluble lignin fraction, a cellulose-enriched carbohydrate pulp was produced, amenable for downstream 
processing [263]. Although promising, the number of OCF studies is still scarce and additional research will be required to support and further develop this strategy. For instance, the fate of the carbohydrate fraction during OCF has to be further investigated and the required high $\mathrm{NaOH}$ concentration is ideally lowered. Also, the implementation of heterogeneous catalysts, as demonstrated earlier for the oxidative depolymerization of lignin model compounds and isolated lignins [153, 154, 264], could benefit the techno-economical aspect of the OCF process.

\subsection{Other Opportunities Towards Higher Lignin Monomer Yields from Native Lignin}

Several other methods have demonstrated the advantage of processing lignocellulosic feedstock instead of isolated lignin for the selective and high yield production of lignin-derived chemicals.

\subsubsection{Thermal (Fast-Pyrolysis)}

A mechanistic pyrolysis study performed by Evans et al. demonstrated that native lignin is much less refractory as commonly believed [265]. A selective initial formation of coniferyl alcohol (CA) and sinapyl alcohol (SA) was observed when processing whole biomass samples, as opposed to identical pyrolysis reactions on several isolated lignins [265]. Consequently, under optimized conditions, an improved production of CA- and SA-derived chemicals has been observed after pyrolysis on lignocellulosic substrates [265-267]. For example, Kuroda et al. reported a threefold increase in the monomer yield after fast-pyrolysis of Japanese softwoods: cedar (23\%), cypress $(21 \%)$, and red pine (18\%) for $4 \mathrm{~s}$ at $773 \mathrm{~K}$, in comparison with the same reaction on the organosolv lignin analogues (yielding 8, 7, and 6\%, respectively) [266]. Main monomer products were guaiacol, 4-methylguaicol, 4-vinylguaiacol, eugenol, and isoeugenol. Nevertheless, due its multicomponent composition, thermal processing of whole biomass will generate a more complex pyrolysis oil, compared to that from isolated lignin, especially in the absence of a catalyst.

\subsubsection{Solvolytic}

Organosolv fractionation typically introduces structural alterations in the lignin polymer (see Sect. 3.3), although milder process variants exist that preserve most $\beta-\mathrm{O}-4$ bonds in the isolated lignin (see Sect. 5.1). On the other hand, organosolv fractionation at high temperatures and short reaction times can also be applied as a method to obtain high lignin monomer yields directly from lignocellulose. Remarkably, methanol:water (90:10) at $543 \mathrm{~K}$ inflicts extensive lignin depolymerization after only 3 min, reaching a high monomer yield of $44 \%$ from beech wood, with a high selectivity towards coniferyl- and sinapyl alcohol, as well as their $\gamma$-methyl ether analogues [108, 109]. The short reaction time is a key aspect to minimize repolymerization reactions and was enabled by immersing a small 5-ml reactor in a molten 
tin bath. The high heating and cooling rate forms a challenging aspect for large-scale batch processes and likely requires a transition to flow-through reactor setups.

\subsubsection{Base-Catalyzed}

Aqueous alkaline pretreatment, a milder version of the traditional soda-pulping process (Sect. 3.1), typically uses less-concentrated $\mathrm{NaOH}$ solutions (0.1-1 $\mathrm{M}$ instead of $2 \mathrm{M}$ ) at temperatures of $373-433 \mathrm{~K}$ for $0.5 \mathrm{~h}$ [268-270]. These mild process conditions are not suitable for efficient ether bond cleavages, but enable a selective conversion of alkali-labile ester linkages, abundantly present in herbaceous crops (e.g., corn stover, switch grass) [55, 195]. This approach is therefore limited to herbaceous feedstocks, from which high phenolic monomer yields of up to $27 \%$ have been achieved [268]. Major monomer products are $p$-coumaric acid, ferulic acid, and vanillic acid.

\subsubsection{Acid-Catalyzed}

Finally, also acid-catalyzed lignocellulose fractionation can be reconciled with high lignin monomer yields. This, however, requires the stabilization of reactive ketoneand aldehyde-substituted intermediates, typically formed under acidic conditions (see Fig. 4). Several mechanisms can be envisioned and are illustrated in Fig. 9.

Barta et al. applied diols to stabilize reactive carbonyl groups through the formation of cyclic acetals (Fig. 9), thereby preventing acid-catalyzed repolymerization $[76,106]$. When ethylene glycol was used in the acid-catalyzed depolymerization (ACD) of walnut dioxasolv lignin, a threefold increase of the lignin monomer yield

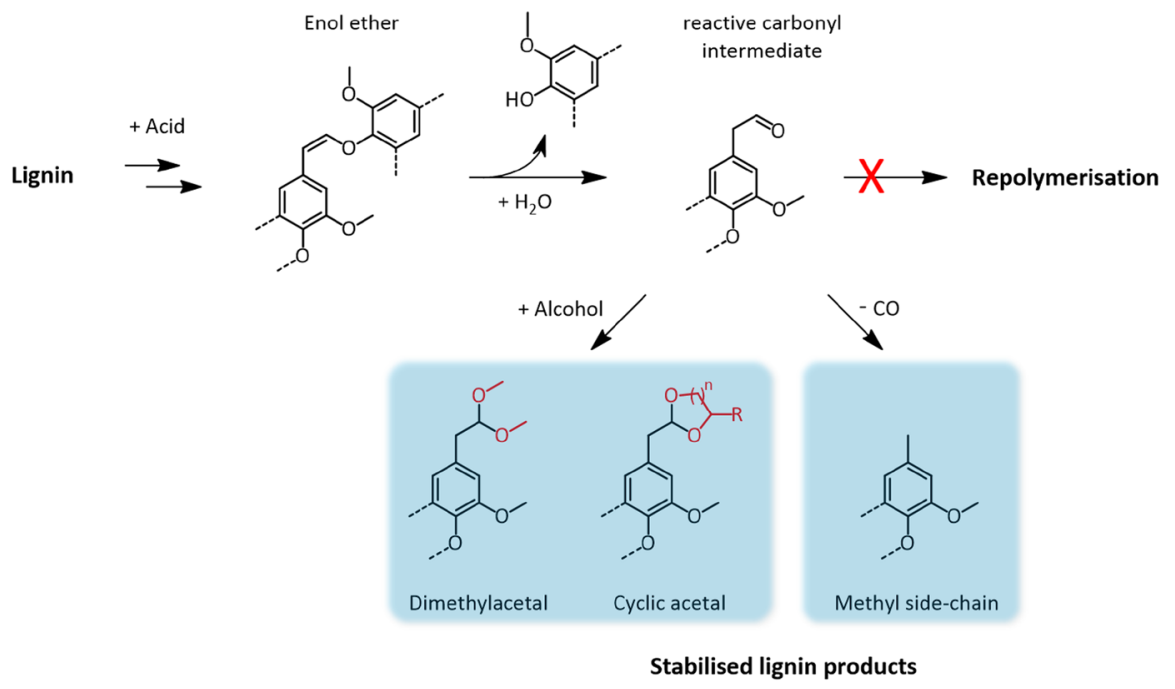

Fig. 9 Lignin stabilization strategies during acid-catalyzed lignin depolymerization/lignocellulose fractionation, converting reactive carbonyl intermediates into acid-stable acetals or methyl groups 
was obtained, compared to ACD in the absence of a diol [76]. A successful implementation of this method, directly on native lignin (i.e., during lignocellulose fractionation) is expected to further improve the achieved monomer yields, but remains to be demonstrated. Note that the underlying chemistry of the cyclic acetal formation is related to the formaldehyde-assisted fractionation, discussed in Sect. 5.2, although in that case the carbonyl group is provided by formaldehyde, which reacts with diol-groups in the lignin side chain. Watanabe et al. applied a similar stabilization approach as Barta et al., though relying on acetal formation with methanol instead of ethylene glycol [271]. During acid-catalyzed fractionation of Japanese cedar in toluene, stable monomeric dimethyl-acetals were obtained this way. Finally, an alternative strategy is to use decarbonylation as a way to remove reactive carbonyl groups. Both homogeneous [76] and heterogeneous [272] catalysts have been applied to convert reactive $\mathrm{C}_{2}$-aldehyde substituted intermediates to stable $p$-methyl substituted products. This approach has not yet been demonstrated on native lignin.

\section{Perspective on Lignin-Derived Chemicals}

Based on the platform of lignin-derived compounds that can be produced via previously described lignocellulose conversion processes, a myriad of end products can be envisioned. These end products can either be obtained through (1) direct utilization/purification of the lignin monomers, or (2) through downstream catalytic upgrading. Furthermore, a distinction is made between drop-in chemicals with an existing market platform, and new chemicals with potentially beneficial properties as a result of their unique chemical functionality. Here, selected examples are provided to illustrate some general principles and strategies. It is also important to note that most of these technologies are still in an early stage of development and require significant further investigation to assess and improve their industrial viability.

\subsection{Direct Utilization}

Obviously, the direct utilization of lignin monomers for chemicals is limited by the product outcome of the lignin depolymerization process. Important criteria that should be assessed are the applicability and the (potential) market value of the targeted product, as well as the yield at which this product can be obtained from lignocellulose. This approach seems especially suitable for chemicals with a relatively high market value to compensate for lower product yields and higher costs, associated with the isolation of pure compounds from potentially complex product mixtures. For instance, vanillin is a high-value flavoring and fragrant component, which is produced at a commercial scale via oxidative depolymerization of sulphite liquor (see Sect. 4.1), despite a rather low product yield ( 5\%) and competing fossil-based routes [144, 145]. Nevertheless, many biorefinery schemes lead to substituted phenolics with no or limited existing applications. A future challenge therefore exists in identifying opportunities for new applications, which exploit the distinguishing functionality (e.g., methoxy groups, side chain) of these lignin monomers. 
For example, several advantages were observed, using either 4- $n$-propylguaiacol or 4- $n$-propylsyrignol in the synthesis of bisguaiacols (BG) or bissyringols (BS), respectively, as biobased alternatives to bisphenol A from phenol [273]. 4-n-propylguaiacol or 4- $n$-propylsyringol were isolated in high yield and selectivity upon RCF of softwoods or hardwoods, respectively (see Sect. 6.1). Compared to phenol, both lignin-derived molecules facilitate $\mathrm{BG} / \mathrm{BS}$ synthesis and purification, reduce the estrogen potency, and introduce advantageous properties in BG polycarbonates, BG cyanate ester resins, and BS polyesters [273, 274]. As such, lignin-derived products potentially carry a competitive advantage, which can open the market to new and valuable chemicals.

\subsection{Chemocatalytic Upgrading}

A second strategy is the catalytic upgrading of lignin-derived compounds, for which both biocatalytic and chemocatalytic approaches exist. Within this context, a variety of chemocatalytic processes have been investigated, though this section is mainly focused on the complete or partial defunctionalization of lignin monomers through hydrodeoxygenation (HDO). An interesting feature of HDO is that complex phenolic mixtures, obtained from lignocellulose processing, can be funneled into a limited number of targeted products. This reduces the complexity of the product mixture and allows a higher yield of individual compounds, while lowering the cost associated with product isolation. As a result of funneling, a high market value (as in the case of vanillin) might not always be required for lignin-derived chemicals to become economically viable. Depending on the process characteristics, chemicals such as (1) alkanes, (2) aromatic hydrocarbons, (3) phenols, or (4) cyclohexanols can be selectively obtained.

Complete defunctionalization of substituted phenolics to alkanes is usually achieved with bifunctional acid-redox catalysis. Various $p$-substituted- $o$-methoxylated phenolics as well as isolated lignin streams (see also bifunctional hydroprocessing in Sect. 4) have been selectively converted to cyclic alkanes, e.g., (alkylated) cyclohexanes [7, 136, 240, 275-279]. The resulting alkane (mixture) could be directly applicable as a mid-range fuel additive, hereby eliminating the need for isolation or purification of individual compounds. Alternatively, HDO can lead to the selective production of aromatics, e.g., (alkylated) benzenes, when conditions are applied that disfavor hydrogenation. Therefore, gas-phase reactions at high temperature and under low $\mathrm{H}_{2}$-pressure have been frequently disclosed, using either traditional sulfided CoMo- and NiMo catalysts or non-sulfided catalysts such as $\mathrm{MoO}_{3}$ or $\mathrm{PtCo} / \mathrm{C}[42,280-282]$.

For the production of phenol or $p$-substituted phenols, the preservation of the phenolic $\mathrm{OH}$-group should be combined with a selective removal of the methoxy group. Again, both traditional sulfided CoMo and NiMo catalysts as well as non-sulfided catalysts (e.g., $\mathrm{Pd} / \mathrm{C}, \mathrm{Fe} / \mathrm{C}, \mathrm{MoC}_{\mathrm{x}} / \mathrm{C}$ ) have been successfully applied, though most studies are limited to the conversion of (alkylated) guaiacols [283-285]. Noticeably, Rinaldi et al. demonstrated the production of alkylated phenols, next to aromatic hydrocarbons, starting from a complex pyrolysis oil using a $\mathrm{MoC}_{\mathrm{x}} / \mathrm{C}$ catalyst 
[284]. Alkylphenols (e.g., 4-ethyl- or 4-propyl phenol), could be further dealkylated towards phenol and the corresponding olefin, viz., ethylene or propylene, as disclosed by Sels and coworkers [286]. A related two-step upgrading strategy is the selective demethoxylation of vanillic and syringic acid towards $p$-hydroxybenzoic acid, i.e., a $p$-substituted phenol, which in turn can be carboxylated to terephthalic acid [287].

Cyclohexanols, the fourth major product class, can be directly obtained through demethoxylation and ring hydrogenation of lignin-derived phenolics. Several catalysts, including $\mathrm{Ni} / \mathrm{CeO}_{2}, \mathrm{Ru}-\mathrm{MnO}_{\mathrm{x}} / \mathrm{C}$, and Raney $\mathrm{Ni}$ have demonstrated high selectivities to (alkylated) cyclohexanols from a variety of substituted phenolics [288-292]. Note that selective removal of $o$-methoxygroups can generate methanol, which for instance could be used as an integrated solvent in the lignocellulosic biorefinery [291]. Moreover, (alkylated) cyclohexanols are readily dehydrogenated to the corresponding ketone, which can be further converted to (alkylated) caprolactone, caprolactam or adipic acid [289, 293]. The non-alkylated analogues are primarily used as building blocks in the production of polyamide (e.g., nylon) and polyesters materials. Interestingly, the alkyl-chain might introduce new and potentially advantageous properties into the polymer, thus creating added value, compared to their fossil-based unsubstituted analogues.

\subsection{Biocatalytic Upgrading}

The biocatalytic upgrading of lignin-derived products is inspired by aromatic catabolic pathways, studied primarily in aerobic micro-organisms [294-296]. In principle, a wide range of aromatic compounds, including $p$-substituted- $o$-methoxylated phenolics, can be enzymatically converted towards a small set of central metabolic intermediates, such as catechol, protocatechuate, and gallate [296-298]. Subsequent opening of the aromatic ring leads these intermediates into the central carbon metabolism. Based on the elucidated enzymatic reaction pathways, research has focused on the metabolic engineering of microbial strains in order to attain a highly selective production of value-added chemicals. For example, using alkaline pretreatment liquor (see Sect. 6.4) as the aromatic substrate, polyhydroxyalkanoates (PHAs) were produced through catabolic reactions in Pseudomonas putida KT2440 [270]. PHAs are valuable polymers that can be used as such in plastics and adhesives, or can be depolymerized and converted to (chiral) chemical precursors or methyl-ester-based fuels [299]. Alternatively, $P$. putida could be engineered towards a selective production of muconic acid via oxidative cleavage of catechol. Amongst others, muconic acid can be further transformed into adipic acid or terephthalic acid, both important polymer building blocks [300, 301]. Also, other bacteria have been studied. For instance, Rhodococcus opacus was grown on a minimal medium containing organosolv lignin (see Sect. 3.3), which led to the production of triacylglycerols, a valuable substrate within the field of oleochemistry (e.g., lubricants) or for the production of biodiesel [302]. Note, that in this study, R. opacus effectuates both lignin depolymerization as well as further metabolic conversion of released phenolic monomers. Although lignin valorization through biocatalysis constitutes a promising strategy, 
future research is likely required to further improve the attainable titers, reactions rates, and yields, as well as the robustness of the biocatalysts towards inhibitors (e.g., toxic aromatic compounds).

\section{Conclusions}

Today, lignin valorization is being recognized as a crucial, yet underexploited component in the lignocellulosic biorefinery. This growing awareness has triggered the development of new technologies, enabling a multitude of future lignin-based applications. One promising opportunity in particular is the selective depolymerization of lignin towards chemicals. Although challenged by lignin's recalcitrant nature, several successful (catalytic) strategies have emerged over the last decade, which were highlighted in this book chapter.

The difficulty of producing chemicals from lignin can be ascribed to the high reactivity of native lignin and its tendency to undergo repolymerization and degradation reactions during lignocellulose fractionation. However, traditional (industrial) fractionation methods have focused primarily on carbohydrate valorization and process conditions have therefore been optimized with little concern about lignin structural alterations. Consequently, commercial lignins embody a challenging feedstock for depolymerization processes, typically leading to low monomer yields and/ or a low product selectivity.

In response, mild fractionation methods have been proposed, isolating lignin with a better preserved structure and an increased amenability towards depolymerization. A high retention of native $\beta-\mathrm{O}-4$ ether bonds can be successfully obtained, while the formation of new recalcitrant $\mathrm{C}-\mathrm{C}$ bonds through repolymerization reactions was largely avoided. Unfortunately, the applied mild conditions usually do not enable high lignin isolation yields. However, to ensure a full utilization of the lignin fraction present in the lignocellulosic feedstock, the structural preservation of lignin and its isolation in high yields should be combined. An alluring strategy is the active stabilization of $\beta-\mathrm{O}-4$ bonds, as recently demonstrated with formaldehyde. This stabilization approach allows a higher process severity, leading to a more complete extraction of lignin, while retaining a high content of readily cleavable $\beta-\mathrm{O}-4$ bonds.

An alternative for the isolation of native-like lignins is the instant depolymerization-stabilization of native lignin towards stable lignin monomers during lignocellulose processing. This approach benefits from depolymerizing lignin in its most reactive form, but requires a fast and efficient stabilization of reactive lignin intermediates in order to minimize lignin repolymerization and maximize the envisioned production of chemicals. Effective stabilization strategies for instance include (1) reductive stabilization, (2) quenching of carbonyl groups through acetal formation, (3) decarbonylation, or (4) a fast physical removal of reactive species from the heating zone.

In conclusion, a selective and high-yield production of lignin-derived platform chemicals can be attained via several strategies as long as three criteria are fulfilled: (1) lignin or lignin-derived products are isolated in high yields, (2) the intrinsic 
reactivity of native lignin towards depolymerization is fully exploited, and (3) a stabilization mechanism is applied to minimize lignin repolymerization.

Finally, lignin-derived platform chemicals could serve as the starting point for a broad range of existing and new bio-based applications. In particular, opportunities exist in the catalytic conversion of these platform compounds towards base chemicals and fuels, as well as specialty chemicals, pharmaceuticals, and materials.

Acknowledgements This work was performed in the framework of SBO projects ARBOREF \& BIOWOOD, EOS project BIOFACT, and Interreg project BIO-HArT. S.V.d.B., T.R., T.V., and W.S. acknowledge the Research Foundation-Flanders (FWO Vlaanderen) for a (post)doctoral fellowship. S.-F.K. acknowledges funding through IWT-SBO project ARBOREF. G.V.d.B acknowledges funding through FISCH-ICON project MAIA.

\section{References}

1. Ragauskas AJ, Williams CK, Davison BH, Britovsek G, Cairney J, Eckert CA, Frederick WJ, Hallett JP, Leak DJ, Liotta CL, Mielenz JR, Murphy R, Templer R, Tschaplinski T (2006) Science 311:484-489

2. Hoffert MI, Caldeira K, Benford G, Criswell DR, Green C, Herzog H, Jain AK, Kheshgi HS, Lackner KS, Lewis JS, Lightfoot HD, Manheimer W, Mankins JC, Mauel ME, Perkins LJ, Schlesinger ME, Volk T, Wigley TML (2002) Science 298:981-987

3. McCormick K, Kautto N (2013) Sustainability 5:2589

4. Dale BE, Kim S (2008) In Biorefineries-industrial processes and products. Wiley, 41-66

5. Kamm B, Gruber PR, Kamm M (eds) (2006) Biorefineries-industrial processes and products. Wiley-VCH, Weinheim

6. Wyman CE (ed) (2013) Aqueous pretreatment of plant biomass for biological and chemical conversion to fuels and chemicals. Wiley, Chichester

7. Deneyer A, Renders T, Van Aelst J, Van den Bosch S, Gabriëls D, Sels BF (2015) Curr Opin Chem Biol 29:40-48

8. Chu S, Majumdar A (2012) Nature 488:294-303

9. Bozell JJ, Holladay JE, Johnson D, White JF (2007) Report PNNL 16983, vol 2, pp 1-79

10. Tuck CO, Pérez E, Horváth IT, Sheldon RA, Poliakoff M (2012) Science 337:695-699

11. Ragauskas AJ, Beckham GT, Biddy MJ, Chandra R, Chen F, Davis MF, Davison BH, Dixon RA, Gilna P, Keller M, Langan P, Naskar AK, Saddler JN, Tschaplinski TJ, Tuskan GA, Wyman CE (2014) Science 344:709

12. Schutyser W, Renders T, Van den Bosch S, Koelewijn SF, Beckham GT, Sels BF (2018) Chem Soc Rev 47:852-908

13. Gosselink RJA, de Jong E, Guran B, Abacherli A (2004) Ind Crops Prod 20:121-129

14. Rinaldi R, Jastrzebski R, Clough MT, Ralph J, Kennema M, Bruijnincx PCA, Weckhuysen BM (2016) Angew Chem Int Ed 55:8164-8215

15. Upton BM, Kasko AM (2016) Chem Rev 116:2275-2306

16. Esposito D, Antonietti M (2015) Chem Soc Rev 44:5821-5835

17. Sen S, Patil S, Argyropoulos DS (2015) Green Chem 17:4862-4887

18. Alonso DM, Hakim SH, Zhou S, Won W, Hosseinaei O, Tao J, Garcia-Negron V, Motagamwala AH, Mellmer MA, Huang K, Houtman CJ, Labbé N, Harper DP, Maravelias C, Runge T, Dumesic JA (2017) Sci Adv 3:1-7

19. Huang Y, Duan Y, Qiu S, Wang M, Ju C, Cao H, Fang Y, Tan T (2017) Sustain Energy Fuels 2:637-647

20. Huber GW, Iborra S, Corma A (2006) Chem Rev 106:4044-4098

21. Bidlack JE, Dashek WV (2016) Plant cells and their organelles. Wiley, Chichester, pp 209-238

22. Clark JH, Deswarte FEI (2008) Introduction to chemicals from biomass. Wiley, Chichester, pp $1-20$

23. Kudakasseril Kurian J, Raveendran Nair G, Hussain A, Vijaya Raghavan GS (2013) Renew Sustain Energy Rev 25:205-219 
24. Himmel ME, Ding SY, Johnson DK, Adney WS, Nimlos MR, Brady JW, Foust TD (2007) Science 315:804-807

25. DeMartini JD, Pattathil S, Miller JS, Li H, Hahn MG, Wyman CE (2013) Energy Environ Sci 6:898-909

26. Davison BH, Parks J, Davis MF, Donohoe BS (2013) Aqueous pretreatment of plant biomass for biological and chemical conversion to fuels and chemicals. Wiley, Chichester, pp 23-38

27. Kumar P, Barrett DM, Delwiche MJ, Stroeve P (2009) Ind Eng Chem Res 48:3713-3729

28. Saini JK, Saini R, Tewari L (2015) 3 Biotech 5:337-353

29. Zakzeski J, Jongerius AL, Bruijnincx PCA, Weckhuysen BM (2012) Chemsuschem 5:1602-1609

30. Klemm D, Heublein B, Fink H-P, Bohn A (2005) Angew Chem Int Ed 44:3358-3393

31. Heinze T (2016) Cellulose chemistry and properties: fibers, nanocelluloses and advanced materials. Rojas OJ (ed) Springer International Publishing, Cham, 2016, pp 1-52

32. Schädel C, Blöchl A, Richter A, Hoch G (2010) Plant Physiol Biochem 48:1-8

33. Girio FM, Fonseca C, Carvalheiro F, Duarte LC, Marques S, Bogel-Lukasik R (2010) Bioresour Technol 101:4775-4800

34. Huang F (2014) Materials for biofuels, World Scientific, pp 1-26

35. U.S Department of Energy Genome Programs image gallery, http://genomics.energy.gov (18/4/2017)

36. Schutyser W, Renders T, Van den Bossche G, Van den Bosch S, Koelewijn S-F, Ennaert T, Sels BF (2017) Nanotechnology in catalysis. Wiley, Chichester, pp 537-584

37. Zakzeski J, Bruijnincx PCA, Jongerius AL, Weckhuysen BM (2010) Chem Rev 110:3552-3599

38. Chundawat SPS, Beckham GT, Himmel ME, Dale BE (2011) Ann Rev Chem Biomol Eng 2:121-145

39. Yuan T-Q, Sun S-N, Xu F, Sun R-C (2011) J Agric Food Chem 59:10604-10614

40. Ralph J, Lundquist K, Brunow G, Lu F, Kim H, Schatz PF, Marita JM, Hatfield RD, Ralph SA, Christensen JH, Boerjan W (2004) Phytochem Rev 3:29-60

41. Vanholme R, Demedts B, Morreel K, Ralph J, Boerjan W (2010) Plant Physiol 153:895-905

42. Laskar DD, Yang B, Wang H, Lee J (2013) Biofuels. Bioprod Biorefining 7:602-626

43. Mottiar Y, Vanholme R, Boerjan W, Ralph J, Mansfield SD (2016) Curr Opin Biotechnol 37:190-200

44. Liu E, Das L, Zhao B, Crocker M, Shi J (2017) BioEnergy Res

45. Brunow G (2008) Biorefineries-Industrial Processes and Products. Wiley, Chichester, pp 151-163

46. Van den Bosch S, Schutyser W, Vanholme R, Driessen T, Koelewijn SF, Renders T, De Meester B, Huijgen WJJ, Dehaen W, Courtin CM, Lagrain B, Boerjan W, Sels BF (2015) Energy Environ Sci $8: 1748-1763$

47. del Rio JC, Rencoret J, Prinsen P, Martinez AT, Ralph J, Gutierrez A (2012) J Agric Food Chem 60:5922-5935

48. Kamm B, Kamm M, Gruber PR, Kromus S (2008) Biorefineries-industrial processes and products. Wiley, Chichester, pp 1-40

49. Mikkola J-P, Sklavounos E, King AWT, Virtanen P (2016) Ionic liquids in the biorefinery concept: challenges and perspectives. The Royal Society of Chemistry, pp 1-37

50. Balat M, Balat H (2009) Appl Energy 86:2273-2282

51. Sánchez ÓJ, Cardona CA (2008) Biores Technol 99:5270-5295

52. Li M, Pu Y, Ragauskas AJ (2016) Front Chem 4:45

53. Zhao X, Zhang L, Liu D (2012) Biofuels. Bioprod Biorefining 6:465-482

54. Lora JH (2016) Quality living through chemurgy and green chemistry. Lau PCK, Springer, pp 221-261

55. Sjöström E (1993) Wood chemistry, 2nd edn. Academic Press, San Diego, pp 114-164

56. Gierer J (1985) Wood Sci Technol 19:289-312

57. Gierer J, Norén I, Wännström S (1987) Journal 41:79

58. Gellerstedt G (2009) Pulping chemistry and technology, pp 91-120

59. Chakar FS, Ragauskas AJ (2004) Ind Crops Prod 20:131-141

60. Gellerstedt G (2015) Ind Crops Prod 77:845-854

61. Ragnar M, Henriksson G, Lindström ME, Wimby M, Blechschmidt J, Heinemann S (2014) Ul1mann's encyclopedia of industrial chemistry. Wiley, Chichester

62. Calvo-Flores FG, Dobado JA, Isac-García J, Martín-MartíNez FJ (2015) Lignin and lignans as renewable raw materials. Wiley, Chichester, pp 113-144

63. Azadi P, Inderwildi OR, Farnood R, King DA (2013) Renew Sustain Energy Rev 21:506-523 
64. Sixta H (1998) Lenzinger Berichte, 18-27

65. Lora J (2008) Monomers, polymers and composites from renewable resources. Gandini MNB (ed) Elsevier, Amsterdam, pp 225-241

66. Aro T, Fatehi P (2017) Chemsuschem 10:1861-1877

67. Gillet S, Aguedo M, Petitjean L, Morais ARC, da Costa Lopes AM, Lukasik RM, Anastas P (2017) Green Chem

68. Anderson S, Dimmel D, Izsak P (2003) J Wood Chem Technol 23:141-159

69. Vishtal AG, Kraslawski A (2011) BioResources 6:3547-3568

70. Luterbacher JS, Martin Alonso D, Dumesic JA (2014) Green Chem 16:4816-4838

71. Katzen R, Schell DJ (2008) Biorefineries-industrial processes and products. Wiley, pp 129-138

72. Pu Y, Hu F, Huang F, Davison BH, Ragauskas AJ (2013) Biotechnol Biofuels 6:15

73. Pu Y, Hu F, Huang F, Ragauskas AJ (2015) BioEnergy Res 8:992-1003

74. Sturgeon MR, Kim S, Lawrence K, Paton RS, Chmely SC, Nimlos M, Foust TD, Beckham GT (2013) ACS Sustain Chem Eng 2:472-485

75. Adler E (1977) Wood Sci Technol 11:169-218

76. Deuss PJ, Scott M, Tran F, Westwood NJ, de Vries JG, Barta K (2015) J Am Chem Soc 137:7456-7467

77. Kulka M, Fisher HE, Baker SB, Hibbert H (1944) J Am Chem Soc 66:39-41

78. Shuai L, Saha B (2017) Green Chem 19:3752-3758

79. Shuai L, Amiri MT, Questell-Santiago YM, Héroguel F, Li Y, Kim H, Meilan R, Chapple C, Ralph J, Luterbacher JS (2016) Science 354:329-333

80. Imai T, Yokoyama T, Matsumoto Y (2011) J Wood Sci 57:219-225

81. Saeman JF, Bubl JL, Harris EE (1945) Ind Eng Chem Anal Ed 17:35-37

82. Bergius $F$ (1937) Ind Eng Chem 29:247-253

83. C. W. Dence, in Methods in Lignin Chemistry, eds. S. Lin and C. Dence, Springer Berlin Heidelberg, 1992, ch. 3, pp 33-61

84. Courtin CM, Van den Broeck H, Delcour JA (2000) J Chromatogr A 866:97-104

85. Zheng Y, Zhao J, Xu F, Li Y (2014) Prog Energy Combust Sci 42:35-53

86. Saeman JF (1945) Ind Eng Chem 37:43-52

87. Hu F, Ragauskas A (2014) RSC Adv 4:4317-4323

88. Hu F, Jung S (2012) Ragauskas, Bioresour Technol 117

89. van Zandvoort I, Koers EJ, Weingarth M, Bruijnincx PCA, Baldus M, Weckhuysen BM (2015) Green Chem 17:4383-4392

90. Nitsos CK, Matis KA, Triantafyllidis KS (2013) Chem Sus Chem 6:110-122

91. Nitsos CK, Choli-Papadopoulou T, Matis KA, Triantafyllidis KS (2016) ACS Sustain Chem Eng 4:4529-4544

92. Sannigrahi P, Ragauskas AJ (2013) Aqueous pretreatment of plant biomass for biological and chemical conversion to fuels and chemicals, Wiley, pp 201-222

93. Zhao X, Cheng K, Liu D (2009) Appl Microbiol Biotechnol 82:815-827

94. Li M-F, Yang S, Sun R-C (2016) Biores Technol 200:971-980

95. Zhang Z, Harrison MD, Rackemann DW, Doherty WOS, O'Hara IM (2016) Green Chem $18: 360-381$

96. Huijgen WJJ, Telysheva G, Arshanitsa A, Gosselink RJA, de Wild PJ (2014) Ind Crops Prod 59:85-95

97. Wildschut J, Smit AT, Reith JH, Huijgen WJJ (2013) Biores Technol 135:58-66

98. Hallac BB, Sannigrahi P, Pu Y, Ray M, Murphy RJ, Ragauskas AJ (2010) Ind Eng Chem Res 24:2723-2732

99. Snelders J, Dornez E, Benjelloun-Mlayah B, Huijgen WJJ, de Wild PJ, Gosselink RJA, Gerritsma J, Courtin CM (2014) Biores Technol 156:275-282

100. Abdelkafi F, Ammar H, Rousseau B, Tessier M, El Gharbi R, Fradet A (2011) Biomacromol 12:3895-3902

101. Grande PM, Viell J, Theyssen N, Marquardt W, Dominguez de Maria P, Leitner W (2015) Green Chem 17:3533-3539

102. Quesada-Medina J, López-Cremades FJ, Olivares-Carrillo P (2010) Biores Technol 101:8252-8260

103. Alriols MG, Tejado A, Blanco M, Mondragon I, Labidi J (2009) Chem Eng J 148:106-114

104. Katahira R, Mittal A, McKinney K, Ciesielski PN, Donohoe BS, Black SK, Johnson DK, Biddy MJ, Beckham GT (2014) ACS Sustain Chem Eng 2:1364-1376

105. Huijgen WJJ, Reith JH, den Uil H (2010) Ind Eng Chem Res 49:10132-10140 
106. Deuss PJ, Lancefield CS, Narani A, de Vries JG, Westwood NJ, Barta K (2017) Green Chem 19:2774-2782

107. Van den Bosch S, Renders T, Kennis S, Koelewijn SF, Van den Bossche G, Vangeel T, Deneyer A, Depuydt D, Courtin CM, Thevelein JM, Schutyser W, Sels BF (2017) Green Chem 19:3313-3326

108. Minami E, Saka S (2003) J Wood Sci 49:0073-0078

109. Minami E, Saka S (2005) J Wood Sci 51:395-400

110. Minami E, Kawamoto H, Saka S (2003) J Wood Sci 49:158-165

111. Bouxin FP, McVeigh A, Tran F, Westwood NJ, Jarvis MC, Jackson SD (2015) Green Chem $17: 1235-1242$

112. Lancefield CS, Rashid GMM, Bouxin F, Wasak A, Tu W-C, Hallett J, Zein S, Rodríguez J, Jackson SD, Westwood NJ, Bugg TDH (2016) ACS Sustain Chem Eng 4:6921-6930

113. Si X, Lu F, Chen J, Lu R, Huang Q, Jiang H, Taarning E, Xu J (2017) Green Chem

114. Ralph SR, Ralph J, Landucci LL. NMR database of lignin and cell wall model compounds. http:// ars.usda.gov/Services/docs.htm?docid=10491

115. Ralph J, Landucci LL (2011) Lignin and lignans: advances in chemistry. Heitner C, Dimmel DR, Schmidt JA. CRC Press, pp 137-244

116. Rolando C, Monties B, Lapierre C (1992) Methods in Lignin Chemistry. Lin SY, Dence CW (eds) Springer, Berlin, pp 334-349

117. Galkin M, Di Francesco D, Edlund U, Samec JSM (2017) Faraday discussions

118. Lancefield CS, Panovic I, Deuss PJ, Barta K, Westwood NJ (2017) Green Chem 19:202-214

119. Zaheer M, Hermannsdörfer J, Kretschmer WP, Motz G, Kempe R (2014) Chemcatchem 6:91-95

120. Galkin MV, Sawadjoon S, Rohde V, Dawange M, Samec JSM (2014) ChemCatChem 6:179-184

121. Parsell TH, Owen BC, Klein I, Jarrell TM, Marcum CL, Haupert LJ, Amundson LM, Kenttamaa HI, Ribeiro F, Miller JT, Abu-Omar MM (2013) Chem Sci 4:806-813

122. Feghali E, Carrot G, Thuery P, Genre C, Cantat T (2015) Energy Environ Sci 8:2734-2743

123. Luterbacher JS, Azarpira A, Motagamwala AH, Lu F, Ralph J, Dumesic JA (2015) Energy Environ Sci 8:2657-2663

124. Kloekhorst A, Shen Y, Yie Y, Fang M, Heeres HJ (2015) Biomass Bioenerg 80:147-161

125. Kumar CR, Anand N, Kloekhorst A, Cannilla C, Bonura G, Frusteri F, Barta K, Heeres HJ (2015) Green Chem 17:4921-4930

126. Oasmaa A, Alén R, Meier D (1993) Biores Technol 45:189-194

127. Huang X, Korányi TI, Boot MD, Hensen EJM (2014) Chemsuschem 7:2276-2288

128. Huang X, Koranyi TI, Boot MD, Hensen EJM (2015) Green Chem 17:4941-4950

129. Torr KM, van de Pas DJ, Cazeils E, Suckling ID (2011) Biores Technol 102:7608-7611

130. Barta K, Warner GR, Beach ES, Anastas PT (2014) Green Chem 16:191-196

131. Molinari V, Clavel G, Graglia M, Antonietti M, Esposito D (2016) ACS Catal 6:1663-1670

132. Ratcliff MA, Johnson DK, Posey FL, Chum HL (1988) Appl Biochem Biotechnol 17:151-160

133. Kloekhorst A, Heeres HJ (2015) ACS Sustain Chem Eng 3:1905-1914

134. Kloekhorst A, Heeres HJ (2016) Catal Sci Technol 6:7053-7067

135. Kasakov S, Shi H, Camaioni DM, Zhao C, Barath E, Jentys A, Lercher JA (2015) Green Chem 17:5079-5090

136. Wang H, Ruan H, Feng M, Qin Y, Job H, Luo L, Wang C, Engelhard MH, Kuhn E, Chen X, Tucker MP, Yang B (2017) Chemsuschem 10:1846-1856

137. Zhang J, Teo J, Chen X, Asakura H, Tanaka T, Teramura K, Yan N (2014) ACS Catal 4:1574-1583

138. Ma R, Hao W, Ma X, Tian Y, Li Y (2014) Angew Chem Int Ed 53:7310-7315

139. Li C, Zhao X, Wang A, Huber GW, Zhang T (2015) Chem Rev 115:11559-11624

140. Ma R, Xu Y, Zhang X (2015) Chemsuschem 8:24-51

141. Ma R, Guo M, Zhang X (2017) Catal Today

142. Gierer J (1986) Wood Sci Technol 20:1-33

143. Demesa AG, Laari A, Turunen I, Sillanpää M (2015) Chem Eng Technol 38:2270-2278

144. Fache M, Boutevin B, Caillol S (2016) ACS Sustain Chem Eng 4:35-46

145. Rodrigues Pinto PC, Borges da Silva EA, Rodrigues AE (2012) Biomass conversion: the interface of biotechnology, chemistry and materials science. Baskar C, Baskar S, Dhillon RS (eds) Springer Berlin, pp 381-420

146. Kagawa S, Rokugawa M (1971) Jpn Tappi J 25:506-511

147. Partenheimer W (2009) Adv Synth Catal 351:456-466

148. Voitl T, Rudolf von Rohr P (2008) ChemSusChem 1:763-769

149. Voitl T, Rohr PRV (2010) Ind Eng Chem Res 49:520-525 
150. Deng W, Zhang H, Wu X, Li R, Zhang Q, Wang Y (2015) Green Chem 17:5009-5018

151. Tarabanko VE, Hendogina YV, Petuhov DV, Pervishina EP (2000) React Kinet Catal Lett 69:361-368

152. Tarabanko VE, Petukhov DV (2003) Chem Sustain Dev 11:655-667

153. Lange H, Decina S, Crestini C (2013) Eur Polymer J 49:1151-1173

154. Das L, Kolar P, Sharma-Shivappa R (2012) Biofuels 3:155-166

155. Werhan H, Assmann N, Rudolf von Rohr P (2013) Chem Eng Process 73:29-37

156. Xiang Q, Lee YY (2000) Appl Biochem Biotechnol 84:153-162

157. Ma R, Guo M, Zhang X (2014) Chemsuschem 7:412-415

158. Hasegawa I, Inoue Y, Muranaka Y, Yasukawa T, Mae K (2011) Energy Fuels 25:791-796

159. Long J, Zhang Q, Wang T, Zhang X, Xu Y, Ma L (2014) Biores Technol 154:10-17

160. Güvenatam B, Heeres EHJ, Pidko EA, Hensen EJM (2016) Catal Today 259:460-466

161. Hepditch MM, Thring RW (2000) Can J Chem Eng 78:226-231

162. Katahira R, Mittal A, McKinney K, Chen X, Tucker MP, Johnson DK, Beckham GT (2016) ACS Sustain Chem Eng 4:1474-1486

163. Beauchet R, Monteil-Rivera F, Lavoie JM (2012) Biores Technol 121:328-334

164. Zhang X, Zhang Q, Long J, Xu Y, Wang T, Ma L, Li Y (2014) BioResources 9:3347-3360

165. Deepa AK, Dhepe PL (2014) RSC Adv 4:12625-12629

166. Lee H-S, Jae J, Ha J-M, Suh DJ (2016) Biores Technol 203:142-149

167. Ye Y, Zhang Y, Fan J, Chang J (2012) Ind Eng Chem Res 51:103-110

168. Ye Y, Fan J, Chang J (2012) J Anal Appl Pyrol 94:190-195

169. Onwudili JA, Williams PT (2014) Green Chem 16:4740-4748

170. Jiang Z, He T, Li J, Hu C (2014) Green Chem 16:4257-4265

171. Bridgwater AV (2012) Biomass Bioenerg 38:68-94

172. Liu C, Wang H, Karim AM, Sun J, Wang Y (2014) Chem Soc Rev 43:7594-7623

173. Mu W, Ben H, Ragauskas A, Deng Y (2013) BioEnergy Res 6:1183-1204

174. Yu Y, Li X, Su L, Zhang Y, Wang Y, Zhang H (2012) Appl Catal A 447:115-123

175. Mihalcik DJ, Mullen CA, Boateng AA (2011) J Anal Appl Pyrol 92:224-232

176. Ma Z, Troussard E, van Bokhoven JA (2012) Appl Catal A 423:130-136

177. Bond JQ, Upadhye AA, Olcay H, Tompsett GA, Jae J, Xing R, Alonso DM, Wang D, Zhang T, Kumar R, Foster A, Sen SM, Maravelias CT, Malina R, Barrett SRH, Lobo R, Wyman CE, Dumesic JA, Huber GW (2014) Energy Environ Sci 7:1500-1523

178. Zhou G, Jensen PA, Le DM, Knudsen NO, Jensen AD (2016) Green Chem 18:1965-1975

179. Thilakaratne R, Tessonnier J-P, Brown RC (2016) Green Chem 18:2231-2239

180. Lazaridis PA, Fotopoulos AP, Karakoulia SA, Triantafyllidis KS (2018) Front Chem 6:1-21

181. Zhao Y, Deng L, Liao B, Fu Y, Guo Q-X (2010) Energy Fuels 24:5735-5740

182. Jackson MA, Compton DL, Boateng AA (2009) J Anal Appl Pyrol 85:226-230

183. Ma Z, Custodis V, van Bokhoven JA (2014) Catal Sci Technol 4:766-772

184. Ennaert T, Van Aelst J, Dijkmans J, De Clercq R, Schutyser W, Dusselier M, Verboekend D, Sels BF (2016) Chem Soc Rev 45:584-611

185. Zhang M, Resende FLP, Moutsoglou A (2014) Fuel 116:358-369

186. Renders T, Van den Bosch S, Koelewijn SF, Schutyser W, Sels BF (2017) Energy Environ Sci 10:1551-1557

187. Barry AJ, Peterson FC, King AJ (1936) J Am Chem Soc 58:333-337

188. Yan MM, Purves CB (1956) Can J Chem 34:1582-1590

189. Bouxin FP, David Jackson S, Jarvis MC (2014) Biores Technol 162:236-242

190. Singh S, Cheng G, Sathitsuksanoh N, Wu D, Varanasi P, George A, Balan V, Gao X, Kumar R, Dale BE, Wyman CE, Simmons BA (2015) Front Energy Res 2

191. da Costa Sousa L, Foston M, Bokade V, Azarpira A, Lu F, Ragauskas AJ, Ralph J, Dale B, Balan V (2016) Green Chem 18:4205-4215

192. Mittal A, Katahira R, Donohoe BS, Pattathil S, Kandemkavil S, Reed ML, Biddy MJ, Beckham GT (2017) ACS Sustain Chem Eng 5:2544-2561

193. Balan V, Bals B, Chundawat SP, Marshall D, Dale BE (2009) Methods Mol Biol 581:61-77

194. Chundawat SPS, Donohoe BS, da Costa Sousa L, Elder T, Agarwal UP, Lu F, Ralph J, Himmel ME, Balan V, Dale BE (2011) Energy Environ Sci 4:973-984

195. Kim JS, Lee YY, Kim TH (2016) Bioresour Technol 199:42-48 
196. Chundawat SPS, Bals B, Campbell T, Sousa L, Gao D, Jin M, Eranki P, Garlock R, Teymouri F, Balan V, Dale BE (2013) Aqueous pretreatment of plant biomass for biological and chemical conversion to fuels and chemicals. Wiley, Chichester, pp 169-200

197. da Costa Sousa L, Jin M, Chundawat SPS, Bokade V, Tang X, Azarpira A, Lu F, Avci U, Humpula J, Uppugundla N, Gunawan C, Pattathil S, Cheh AM, Kothari N, Kumar R, Ralph J, Hahn MG, Wyman CE, Singh S, Simmons BA, Dale BE, Balan V (2016) Energy Environ Sci 9:1215-1223

198. Chundawat SPS, Bellesia G, Uppugundla N, da Costa Sousa L, Gao D, Cheh AM, Agarwal UP, Bianchetti CM, Phillips GN, Langan P, Balan V, Gnanakaran S, Dale BE (2011) J Am Chem Soc 133:11163-11174

199. Kim TH, Lee YY (2005) Biores Technol 96:2007-2013

200. Kim TH, Kim JS, Sunwoo C, Lee YY (2003) Biores Technol 90:39-47

201. Yang B, Wyman CE (2008) Biofuels Bioprod Biorefining-Biofpr 2:26-40

202. Yoon HH, Wu ZW, Lee YY (1995) Appl Biochem Biotechnol 51:5-19

203. Brandt A, Grasvik J, Hallett JP, Welton T (2013) Green Chem 15:550-583

204. George A, Tran K, Morgan TJ, Benke PI, Berrueco C, Lorente E, Wu BC, Keasling JD, Simmons BA, Holmes BM (2011) Green Chem 13:3375-3385

205. Badgujar KC, Bhanage BM (2015) Biores Technol 178:2-18

206. Brandt-Talbot A, Gschwend FJV, Fennell PS, Lammens TM, Tan B, Weale J, Hallett JP (2017) Green Chem 19:3078-3102

207. Weigand L, Mostame S, Brandt-Talbot A, Welton T, Hallett JP (2017) Faraday Discuss 18

208. Zhang Q, De Oliveira Vigier K, Royer S, Jerome F (2012) Chem Soc Rev 41:7108-7146

209. Petkovic M, Seddon KR, Rebelo LPN, Silva C (2011) Pereira. Chem Soc Rev 40:1383-1403

210. Yan L, Zhang L, Yang B (2014) Biotechnol Biofuels 7:76

211. Wang H, Ben H, Ruan H, Zhang L, Pu Y, Feng M, Ragauskas AJ, Yang B (2017) ACS Sustain Chem Eng 5:1824-1830

212. Liu C, Wyman CE (2003) Ind Eng Chem Res 42:5409-5416

213. Bhagia S, Li H, Gao X, Kumar R, Wyman CE (2016) Biotechnol Biofuels 9:245

214. Luterbacher JS, Rand JM, Alonso DM, Han J, Youngquist JT, Maravelias CT, Pfleger BF, Dumesic JA (2014) Science 343:277-280

215. Alonso DM, Wettstein SG, Mellmer MA, Gurbuz EI, Dumesic JA (2013) Energy Environ Sci 6:76-80

216. Mellmer MA, Sener C, Gallo JMR, Luterbacher JS, Alonso DM, Dumesic JA (2014) Angew Chem Int Ed 53:11872-11875

217. Shuai L, Luterbacher J (2016) Chemsuschem 9:133-155

218. Shuai L, Questell-Santiago YM, Luterbacher JS (2016) Green Chem 18:937-943

219. Barakat A, Mayer-Laigle C, Solhy A, Arancon RAD, de Vries H, Luque R (2014) RSC Advances 4:48109-48127

220. Rencoret J, Marques G, Gutiérrez A, Nieto L, Jiménez-Barbero J, Martínez ÁT, del Río JC (2009) Ind Crops Prod 30:137-143

221. El Hage R, Brosse N, Chrusciel L, Sanchez C, Sannigrahi P, Ragauskas A (2009) Polym Degrad Stab 94:1632-1638

222. Guerra A, Mendonça R, Ferraz A, Lu F, Ralph J (2004) Appl Environ Microbiol 70:4073-4078

223. Tolbert A, Akinosho H, Khunsupat R, Naskar AK, Ragauskas AJ (2014) Biofuels Bioprod Biorefining 8:836-856

224. Hu Z, Yeh T-F, Chang HM, Matsumoto Y, Kadla John F (2006) Journal 60:389

225. Chang HM, Cowling Ellis B, Brown W (1975) Journal 29:153

226. Guerra A, Filpponen I, Lucia LA, Argyropoulos DS (2006) J Agric Food Chem 54:9696-9705

227. Guerra A, Filpponen I, Lucia LA, Saquing C, Baumberger S, Argyropoulos DS (2006) J Agric Food Chem 54:5939-5947

228. van der Klashorst GH (1989) Lignin. American Chemical Society, vol. 397, ch. 26, pp 346-360

229. Wu L, Talebi AM (2018) Angewandte Chemie International Edition 57:1356-1360

230. Bower JR, Cooke LM, Hibbert H (1943) J Am Chem Soc 65:1192-1195

231. Brewer CP, Cooke LM, Hibbert H (1948) J Am Chem Soc 70:57-59

232. Pepper JM, Brounstein CJ, Shearer DA (1951) J Am Chem Soc 73:3316-3319

233. Pepper JM, Supathna P (1978) Can J Chem 56:899-902

234. Song Q, Wang F, Cai JY, Wang YH, Zhang JJ, Yu WQ, Xu J (2013) Energy Environ Sci 6:994-1007 
235. Anderson EM, Stone ML, Katahira R, Reed M, Beckham GT, Román-Leshkov Y (2017) Joule 1:613-622

236. Kumaniaev I, Subbotina E, Savmarker J, Larhed M, Galkin MV, Samec JSM (2017) Green Chem 19:5767-5771

237. Anderson EM, Katahira R, Reed M, Resch MG, Karp EM, Beckham GT, Román-Leshkov Y (2016) ACS Sustain Chem Eng

238. Renders T, Schutyser W, Van den Bosch S, Koelewijn S-F, Vangeel T, Courtin CM, Sels BF (2016) Acs Catal 6:2055-2066

239. Ferrini P, Rezende CA, Rinaldi R (2016) Chemsuschem 9:3171-3180

240. Yan N, Zhao C, Dyson PJ, Wang C, Liu LT, Kou Y (2008) Chemsuschem 1:626-629

241. Galkin MV, Samec JSM (2016) Chemsuschem 9:1544-1558

242. Galkin MV, Samec JSM (2014) Chemsuschem 7:2154-2158

243. Parsell T, Yohe S, Degenstein J, Jarrell T, Klein I, Gencer E, Hewetson B, Hurt M, Kim JI, Choudhari H, Saha B, Meilan R, Mosier N, Ribeiro F, Delgass WN, Chapple C, Kenttamaa HI, Agrawal R, Abu-Omar MM (2015) Green Chem 17:1492-1499

244. Ferrini P, Rinaldi R (2014) Angewandte Chemie-International Edition 53:8634-8639

245. Luo H, Klein IM, Jiang Y, Zhu H, Liu B, Kenttämaa HI, Abu-Omar MM (2016) ACS Sustain Chem Eng 4:2316-2322

246. Schutyser W, Van den Bosch S, Renders T, De Boe T, Koelewijn SF, Dewaele A, Ennaert T, Verkinderen O, Goderis B, Courtin CM, Sels BF (2015) Green Chem 17:5035-5045

247. Renders T, Van den Bosch S, Vangeel T, Ennaert T, Koelewijn S-F, Van den Bossche G, Courtin CM, Schutyser W, Sels BF (2016) ACS Sustain Chem Eng 4:6894-6904

248. Huang X, Morales Gonzalez OM, Zhu J, Koranyi TI, Boot MD, Hensen EJM (2017) Green Chem 19:175-187

249. Huang X, Zhu J, Korányi TI, Boot MD, Hensen EJM (2016) Chemsuschem

250. Galkin MV, Smit AT, Subbotina E, Artemenko KA, Bergquist J, Huijgen WJJ, Samec JSM (2016) Chemsuschem 9:3280-3287

251. Anderson EM, Stone ML, Hülsey MJ, Beckham GT, Román-Leshkov Y (2018) ACS Sustain Chem Eng 6:7951-7959

252. Van den Bosch S, Schutyser W, Koelewijn S-F, Renders T, Courtin CM, Sels BF (2015) Chem Commun

253. Pepper JM, Lee YW (1969) Can J Chem 47:723-727

254. Li C, Zheng M, Wang A, Zhang T (2012) Energy Environ Sci 5:6383-6390

255. Matson TD, Barta K, Iretskii AV, Ford PC (2011) J Am Chem Soc 133:14090-14097

256. Barta K, Ford PC (2014) Acc Chem Res 47:1503-1512

257. Op de Beeck B, Dusselier M, Geboers J, Holsbeek J, Morre E, Oswald S, Giebeler L, Sels BF (2015) Energy Environ Sci 8:230-240

258. Deneyer A, Ennaert T, Cavents G, Dijkmans J, Vanneste J, Courtin CM, Dusselier M, Sels BF (2016) Green Chem 18:5594-5606

259. Xia Q, Chen Z, Shao Y, Gong X, Wang H, Liu X, Parker SF, Han X, Yang S, Wang Y (2016) 7:11162

260. Chen C-L (1992) Methods in lignin chemistry. Lin SY, Dence CW (eds) Springer, Berlin, pp 301-321

261. Pepper JM, Casselman BW, Karapally JC (1967) Can J Chem 45:3009-3012

262. Koropachinskaya N, Tarabanko V, Chernyak M (2003) Chem Plant Raw Mater (Russia), 9-14

263. Kuznetsov BN, Kuznetsova SA, Danilov VG, Tarabanko VE (2005) Chem Sustain Dev 13:531-539

264. Behling R, Valange S, Chatel G (2016) Green Chem 18:1839-1854

265. Evans RJ, Milne TA, Soltys MN (1986) J Anal Appl Pyrol 9:207-236

266. Kuroda K-I, Inoue Y, Sakai K (1990) J Anal Appl Pyrol 18:59-69

267. Kotake T, Kawamoto H, Saka S (2015) J Anal Appl Pyrol 113:57-64

268. Karp EM, Nimlos CT, Deutch S, Salvachua D, Cywar RM, Beckham GT (2016) Green Chem 18:4750-4760

269. Karp EM, Resch MG, Donohoe BS, Ciesielski PN, O’Brien MH, Nill JE, Mittal A, Biddy MJ, Beckham GT (2015) ACS Sustain Chem Eng 3:1479-1491

270. Linger JG, Vardon DR, Guarnieri MT, Karp EM, Hunsinger GB, Franden MA, Johnson CW, Chupka G, Strathmann TJ, Pienkos PT, Beckham GT (2014) Proc Natl Acad Sci 111:12013-12018

271. Kaiho A, Kogo M, Sakai R, Saito K, Watanabe T (2015) Green Chem 17:2780-2783 
272. Jastrzebski R, Constant S, Lancefield CS, Westwood NJ, Weckhuysen BM, Bruijnincx PCA (2016) Chemsuschem 9:2074-2079

273. Koelewijn S-F, Van den Bosch S, Renders T, Schutyser W, Lagrain B, Smet M, Thomas J, Dehaen W, Van Puyvelde P, Witters H, Sels BF (2017) Green Chem 19:2561-2570

274. Koelewijn SF, Cooreman C, Renders T, Andecochea Saiz C, Van den Bosch S, Schutyser W, De Leger W, Smet M, Van Puyvelde P, Witters H, Van der Bruggen B, Sels BF (2018) Green Chem 20:1050-1058

275. Zhao C, Kou Y, Lemonidou AA, Li X, Lercher JA (2009) Angewandte Chemie-International Edition 48:3987-3990

276. Yan N, Yuan Y, Dykeman R, Kou Y, Dyson PJ (2010) Angew Chem Int Ed 49:5549-5553

277. Zhang W, Chen J, Liu R, Wang S, Chen L, Li K (2014) ACS Sustain Chem Eng 2:683-691

278. Luska KL, Migowski P, El-Sayed S, Leitner W (2015) Angew Chem Int Ed 54:15750-15755

279. Wang H, Wang H, Kuhn E, Tucker MP, Yang B (2017) ChemSusChem

280. Yohe SL, Choudhari HJ, Mehta DD, Dietrich PJ, Detwiler MD, Akatay CM, Stach EA, Miller JT, Delgass WN, Agrawal R, Ribeiro FH (2016) J Catal 344:535-552

281. Prasomsri T, Shetty M, Murugappan K, Roman-Leshkov Y (2014) Energy Environ Sci 7:2660-2669

282. Wang H, Male J, Wang Y (2013) ACS Catal 3:1047-1070

283. Sun J, Karim AM, Zhang H, Kovarik L, Li XS, Hensley AJ, McEwen J-S, Wang Y (2013) J Catal 306:47-57

284. Cao Z, Engelhardt J, Dierks M, Clough MT, Wang G-H, Heracleous E, Lappas A, Rinaldi R, Schüth F (2017) Angew Chem Int Ed 56:2334-2339

285. Joshi N, Lawal A (2013) Ind Eng Chem Res 52:4049-4058

286. Verboekend D, Liao Y, Schutyser W, Sels BF (2016) Green Chem 18:297-306

287. Bai Z, Phuan WC, Ding J, Heng TH, Luo J, Zhu Y (2016) ACS Catal 6:6141-6145

288. Schutyser W, Van den Bossche G, Raaffels A, Van den Bosch S, Koelewijn S-F, Renders T, Sels BF (2016) ACS Sustain Chem Eng 4:5336-5346

289. Schutyser W, Van den Bosch S, Dijkmans J, Turner S, Meledina M, Van Tendeloo G, Debecker DP, Sels BF (2015) Chemsuschem 8:1805-1818

290. Wang XY, Rinaldi R (2012) Energy Environ Sci 5:8244-8260

291. Nakagawa Y, Ishikawa M, Tamura M, Tomishige K (2014) Green Chem 16:2197-2203

292. Ishikawa M, Tamura M, Nakagawa Y, Tomishige K (2016) Appl Catal B 182:193-203

293. Dijkmans J, Schutyser W, Dusselier M, Sels BF (2016) Chem Commun 52:6712-6715

294. Jiménez JI, Miñambres B, García JL, Díaz E (2002) Environ Microbiol 4:824-841

295. Barbe V, Vallenet D, Fonknechten N, Kreimeyer A, Oztas S, Labarre L, Cruveiller S, Robert C, Duprat S, Wincker P, Ornston LN, Weissenbach J, Marliere P, Cohen GN, Medigue C (2004) Nucleic Acids Res 32:5766-5779

296. Masai E, Kamimura N, Kasai D, Oguchi A, Ankai A, Fukui S, Takahashi M, Yashiro I, Sasaki H, Harada T, Nakamura S, Katano Y, Narita-Yamada S, Nakazawa H, Hara H, Katayama Y, Fukuda M, Yamazaki S, Fujita N (2012) J Bacteriol 194:534-535

297. Bugg TDH, Ahmad M, Hardiman EM, Rahmanpour R (2011) Nat Prod Rep 28:1883-1896

298. Masai E, Katayama Y, Fukuda M (2007) Biosci Biotechnol Biochem 71:1-15

299. Chen GQ (2009) Chem Soc Rev 38:2434-2446

300. Vardon DR, Franden MA, Johnson CW, Karp EM, Guarnieri MT, Linger JG, Salm MJ, Strathmann TJ, Beckham GT (2015) Energy Environ Sci 8:617-628

301. Xie N-Z, Liang H, Huang R-B, Xu P (2014) Biotechnol Adv 32:615-622

302. Kosa M, Ragauskas AJ (2013) Green Chem 15:2070-2074 